Western University

Scholarship@Western

Geography Publications

Geography Department

2017

\title{
Morpho-sedimentary characteristics of proximal gravel braided river deposits in a Froude-scaled physical model
}

Peter Ashmore

pashmore@uwo.ca

Tobias Gardner

Pauline Leduc

Follow this and additional works at: https://ir.lib.uwo.ca/geographypub

Part of the Geomorphology Commons, Physical and Environmental Geography Commons, and the Sedimentology Commons

Citation of this paper:

Ashmore, Peter; Gardner, Tobias; and Leduc, Pauline, "Morpho-sedimentary characteristics of proximal gravel braided river deposits in a Froude-scaled physical model" (2017). Geography Publications. 357.

https://ir.lib.uwo.ca/geographypub/357 
DR. TOBI GARDNER (Orcid ID : 0000-0002-9434-3420)

Article type : Original Manuscript

Corresponding author mail id:- tobigardner@gmail.com

\title{
Morpho-sedimentary characteristics of proximal gravel braided river deposits in a Froude-scaled physical model
}

\author{
Tobi Gardner1, Peter Ashmore, and Pauline Leduc
}

Department of Geography, Western University, London, Ontario, Canada

${ }^{1}$ Now at Capital Region District, Victoria BC Canada

\section{Associate Editor - Vern Manville \\ Short Title - Morpho-sedimentary of proximal braided river deposits}

\begin{abstract}
A Froude-scaled physical model of a proximal gravel-bed braided river was used to connect the river morphological characteristics, and sedimentary processes and forms, to deposit geometry. High resolution continuous three-dimensional topographic data was acquired from sequential photogrammetric digital elevation models paired with grain-size surface maps derived from image analysis of textural properties of the surface. From these data the full three-dimensional development of the braided river deposit and grain-size sorting patterns was compiled over an experimental time period of 40 hours during which the model river reworked a large This article has been accepted for publication and undergone full peer review but has not been through the copyediting, typesetting, pagination and proofreading process, which may lead to differences between this version and the Version of Record. Please cite this article as doi: $10.1111 /$ sed. 12409

This article is protected by copyright. All rights reserved.
\end{abstract}


portion of the braided channel. The minimum surface of the deposit is developed progressively over time by erosion, migration and avulsion of channels, and by local scour at channel confluences. The maximum surface of the deposit is formed by amalgamation of braid bar surfaces and has less overall relief than the minimum surface. Confluence scour constitutes about $5 \%$ of the area of the minimum surface. Migration of individual confluences is limited to distances of the order of the width and length of the confluence so that confluences do not form laterally extensive deposits and basal surfaces. Maximum and minimum surfaces have very similar grain-size distributions, and there is no extensive basal coarse layer. Deposit maximum thickness is strongly associated with large channel confluences which occur as deeper areas along the main channel belt and make up a large proportion of the thickest portions of the deposit.

Keywords: Braided river sedimentology, confluence deposits, deposit geometry, morphosedimentary processes, physical-scale modelling.

\section{INTRODUCTION}

Gravel-braided river bed deposit geometry and grain-size sorting patterns are controlled by channel-scale topography, grain-size distributions, pattern geometry and kinetics, and bar and bedform characteristics (Bluck, 1974, 1979; Boothroyd \& Ashley, 1975; Bridge 1993; Ashworth et al., 1999; Moreton et al, 2002; Lunt \& Bridge, 2004; Bridge \& Lunt, 2006; van de Lageweg et al. 2013a). Research on modern gravel braided river deposits from field documentation and physical models has shown that they consist of an array of remnants of bars, channel and scour fills and larger-scale bar assemblages (McDonald \& Banerjee, 1971; Smith, 1974; Boothroyd \& 
Ashley, 1975; Bluck, 1974, 1979; Hein \& Walker, 1977; Moreton et al, 2002; Sheets et al., 2002; Lunt \& Bridge, 2004; Lunt et al., 2004; Bridge \& Lunt, 2006). Bars form by gradual lateral and downstream accretion of initial unit bars (Smith, 1974; Ashmore, 1982; Bridge 1993 and 2003), and by a combination of lateral migration and secondary braiding or 'partial avulsion' (e.g. Ashmore, 1982; Leddy et al., 1993; Egozi \& Ashmore, 2009). Coarse-grained gravelly braided deposits are made up of poorly-sorted, horizontally-bedded stratified sheets with bedding planes that are roughly parallel to the bar surface with channel units identifiable in cross-section in aggraded deposits (MacDonald \& Banerjee, 1971; Boothroyd \& Ashley, 1975; Church \& Gilbert, 1975; Rust, 1975; Hein \& Walker, 1977; Bluck, 1979, Steel \& Thompson, 1983; Moreton et al., 2002; Lunt \& Bridge, 2004; Lunt et al., 2004). At channel reach scale, considerable local variability in strata characteristics and grain size is the result of complex and variable histories of bar deposition and development (Bluck, 1979).

Particularly in pro-glacial settings, there are well-documented transitions in modern channel and bar morphology and sedimentary processes and deposits from (ice) proximal to distal locations covering a range of channel and sedimentary characteristics (MacDonald \& Banerjee, 1971; Smith, 1974; Boothroyd \& Ashley, 1975; Church \& Gilbert, 1975; Rust, 1975; Hein \& Walker, 1977; Marren, 2005). In particular, the proximal-distal transition is one of increasing depth relative to grain size, and increasing sediment mobility, accompanied by changes in dominant bar forms from longitudinal with height similar to $\mathrm{D}_{90}$ no slip face to multi-lobate linguoid forms with frequent lee slip faces. Bedding characteristics transition from horizontal to cross-bedded in this transition of bar types. Larger scale trough crossbedding has been documented in Pleistocene deposits of what are presumably much 
larger scale rivers with large-scale multi-lobate, linguoid bedforms (e.g. Church \& Gilbert, 1975; Rust, 1975; Siegenthaler \& Huggenberger, 1993; Beres et al., 1999; Huggenberger \& Regli, 2006)

Quantitative analysis of braiding deposit set thicknesses (van de Lageweg et al., 2013a) from a small-scale river model has shown that set thickness is tied to channel scale morphological processes and is typically equivalent to 10 to $40 \%$ of channel depth, with one to three vertical sets in most locations. Bar and channel fill deposits have a range of sorting patterns with weak horizontal, or slightly inclined, stratification and may appear stacked and cyclic (Smith, 1974; Miall, 1977; Bluck, 1979; Bentham et al., 1993; Sambrook-Smith, 2000; Bridge \& Lunt 2006; Marren, 2005). Grain size varies between bedding units but there is little evidence for distinct vertical trends in grain size in the gravel size fraction and channel deposits (as distinct from overbank sediments) (Boothroyd \& Ashley, 1975, fig. 25; Bluck 1979; Heintz et al., 2003; Lunt \& Bridge, 2004; Lunt et al., 2004; Marren, 2005; Guerit et al, 2014).

Scour at anabranch confluences is a significant feature of gravel braided river morphology and sediment transport (Ashmore, 1993, 2013; Bridge, 1993; Bridge, 2003; Ashmore \& Gardner, 2008) related to the distinctive secondary flow structure (Bridge, 2003). Scour occurs at the intersection of the main active channels of the braided river around major braid bars and therefore scour areas form, migrate and infill as the confluent anabranches change morphology and position, and shift location by local avulsion (Ashmore, 1993). The dimensions of confluence scour holes are controlled by the total flow through the confluence and secondarily by the confluence angle and symmetry (Ashmore \& Parker, 1983). Because gravel braided anabranches have typically low sinuosity, scour at bends and bar margins may be less 
pronounced than at confluences (Ashmore \& Gardner, 2008; Ashmore, 2013). Scour at anabranch confluences is likely to exert strong local control on deposit geometry and potentially lead to diagnostic deposit characteristics (Ashmore \& Parker, 1983; Klaassen \& Vermeer, 1988; Bridge, 1993; Bristow et al., 1993; Siegenthaler \& Huggenberger, 1993; Best \& Ashworth, 1997; Leclair et al., 1997; Miall \& Jones, 2003; Marren, 2005; Sambrook-Smith et al., 2006; Gardner \& Ashmore, 2011), although earlier studies of pro-glacial alluvium make little mention of these features (Smith, 1974; Boothroyd \& Ashley, 1975; Church \& Gilbert, 1975; Rust, 1975; Hein \& Walker, 1977). Confluences may migrate laterally and longitudinally, but direct evidence and data on migration distances is very limited (Best \& Rhoads, 2008; Ashmore \& Gardner, 2008). Ashmore (1993) shows examples of confluence adjustment in a physical model but observed only relatively short (less than the confluence dimensions) migration distances. It is possible that confluence deposits may comprise a significant proportion of the preserved river deposits overall (Huggenberger \& Regli, 2006), although this may vary in the proximal-distal transition (Siegenthaler \& Huggenberger, 1993), and that basal surfaces may be formed by extensive migration of confluence scour (Best \& Ashworth, 1997). Confluences are mentioned in sedimentological syntheses of braided river deposits (Bridge, 1993; Lunt et al., 2004; Bridge \& Lunt, 2006; Marren, 2005; Miall, 2014) and the occurrence of open-framework gravel at the lower erosion surface has been interpreted to represent confluence scour sediments in some cases (Siegenthaler \& Huggenberger, 1993; Lunt et al., 2004; Wooldridge \& Hickin, 2005). However, to date, confluence-related contributions to braided river deposit geometry and sedimentology have not been analyzed quantitatively and from direct observations of deposit formation. 
Further data on the processes affecting deposit geometry and granulometry in three-dimensions and directly observed during active formation of the deposits would aid process-based understanding and quantitative information on gravelly braided alluvium, including the contribution from anabranch confluence zones. Small-scale physical models have been shown to be a useful source of this type of quantitative information in both aggradational and non-aggradational conditions for braiding and other river planforms (e.g. Peakall, 1996; Moreton et al., 2002; Paola et al., 2009; van de Lageweg et al, 2013a,b; Van dijk et al 2012 and 2013; Kleinhans \& Van den Berg, 2011).

The objective of this study is to expand and extend previous analysis of data from a physical model of a gravel braided river (Gardner \& Ashmore, 2011; Leduc at et al. 2015) to document the quantitative three-dimensional geometry of proximal gravelly braided alluvium, including channel confluence deposits and their contribution to deposit geometry. A quantification of this kind from physical model data has not been done previously. This approach is referred to herein as the morpho-sedimentary characteristics of gravel braided rivers to signal the explicit quantitative linking of the known bar-scale morphology and morphological changes to the deposit geometry and granulometry. This analysis of deposit geometry during formation complements existing facies and stratal analyses, gravel braided river alluvium from field investigations (Boothroyd \& Ashley, 1975; Bluck, 1979; Bridge \& Lunt, 2006), and previous analysis from physical models for a range of river types (Moreton et al., 2002; van de Lageweg et al, 2013a,b; Van dijk et al. 2012 and 2013; Kleinhans \& Van den Berg, 2011). 


\section{METHODS:}

\section{Physical Model}

A Froude-scale physical model (Peakall et al., 1996; Young \& Warburton, 1996) was used to simulate a gravel-bed braided river (Fig. 1) to give geometric, kinematic and dynamic similarity between the model and the full scale river. The flume is $18 \mathrm{~m}$ long and $3 \mathrm{~m}$ wide, and the model was scaled to a pro-glacial river at a field site in the Canadian Rockies (see Ashmore et al., 2011) at approximately 1:30 length ratio under constant discharge of $2.1 \mathrm{l} / \mathrm{s}$ (equivalent to about $12 \mathrm{~m}^{3} \mathrm{~s}^{-1}$ in the pro-glacial river, which is a typical diurnal peak flow of that river during meltwater season) and slope of $1.5 \%$. The grain-size distribution was used as the primary geometric scale ratio and the complete gravel grain-size distribution was scaled geometrically in the model (Fig. 2). The grain sizes in the model range from $0.17 \mathrm{~mm}$ to $16 \mathrm{~mm}$, with $\mathrm{D}_{50}$ of approximately $1.3 \mathrm{~mm}$ and $\mathrm{D}_{90}$ of $3.6 \mathrm{~mm}$ (Fig. 2). The distribution was truncated at the fine end (equivalent to about 4 to $5 \mathrm{~mm}$ in the prototype) to avoid particle suspension (turbidity) and formation of ripples in the model, so as to preserve hydraulic (for example, form and grain resistance) and gravel bedform similarity. Consequently the sand fraction in the full scale river is not represented in the model. The consequences of this are not known in detail but gravel transport dominates the morphology and overall dynamics of this type of braided river so that overall gravel deposit dimensions are expected to be similar between model and the full scale river. In the full scale river, sand occurs mainly as matrix in the gravel and locally as very thin slack water deposits (Boothroyd \& Ashley, 1975; Bluck, 1979; Sambrook Smith, 2000). Froude scaling preserves the same non-dimensional bed shear stress (Shields parameter) in the model as in the full scale river across all size fractions so that bed material mobility, transport conditions and sorting are reproduced in the model 
along with morphological similarity (Ashmore, 1982, Ashmore \& Parker, 1983, Peakall et al., 1996; Young \& Warburton, 1996). Channel depths are of the order of a maximum of 10 times $\mathrm{D}_{90}$ so that flows are relatively shallow, Reynolds numbers are relatively low but flow is turbulent or transitional and boundaries are hydraulically rough (Gardner, 2009). For channel depth of 0.03m (typical of larger channels in the model), Shields stress is of the order of 0.21 for $\mathrm{D}_{50}$ and 0.075 for $\mathrm{D}_{90}$. At lower depths partial transport (limited mobility of the largest grains) will occur, as it would in the full scale river. Bedforms are dominated by planar gravel sheets and unit bars; no dune-like bedforms or ripples occur. While scaled to a particular site the model generically represents conditions in other proximal (low depth/grain size ratio) gravel braided rivers.

Discharge was constant throughout the experiment as an experimental simplification against which varying discharge data might later be compared. Flow was turned off hourly to acquire dry-bed images for photogrammetry. Sediment was recirculated so that the experiments were run in net equilibrium in terms of total sediment mass balance. The net equilibrium state was chosen so as to isolate the connection between channel morphology and the resulting deposit geometry and grain-size characteristics without the influence of overall aggradation or aggradation rate (see also van de Lageweg et al., 2013 a,b). Successive digital elevation models (DEMs) over the course of the experiment show some overall redistribution of sediment within the flume so that slight (a few millimetres) net aggradation occurred within the $10 \mathrm{~m}$ length used for data collection. The experiment simulated the morpho-dynamics and floodplain reworking of the river over a time period sufficient to rework a large area of the river bed within the model and for substantial channel pattern development and topographic changes to occur. The 41 hours of flume time, 
assuming 'bankfull' conditions occurring only a few days per year, represents several years of development in a full scale river.

The experiment was run for an extended period of over 200 hours and a sample period of 41 hours was selected for analysis (experiment hours 139 to 179). The flume bed was fully braided during this time and some of the braiding bed features were inherited from earlier in the experiment. Orthophotographs and DEMs were extracted from hourly images of the dry bed surface during this time period. This approach allowed for high-frequency measurements of the river bed deposit (see also van de Lageweg., et al 2013a). Further details of the experiments and model river morphology are also in Gardner \& Ashmore (2011) and Egozi \& Ashmore (2008, 2009).

\section{Photogrammetry}

The source data are DEMs and grain size maps acquired hourly with vertical stereo photos of the riverbed (with flow turned off) using a 6.3 mega-pixel Canon 10D digital camera using a Canon $20 \mathrm{~mm}$ lens (Canon, Tokyo, Japan). The camera was secured to a platform that ran the length of the flume on rails attached to the roof trusses in the ceiling of the laboratory. For these experiments, the external selfcalibrating bundle adjustment program GAP (Chandler \& Clark, 1992) was used to estimate the camera parameters (Chandler et al., 2005; Wackrow et al., 2008).

The camera was remotely triggered and photographs overlapped by approximately $75 \%$ and covered a $3 \mathrm{~m}$ width and $12 \mathrm{~m}$ length of the flume. A ground control point (GCP) network of 74 control points was set up in the river model for photogrammetric control. Twenty-one (28\%) of the GCPs distributed throughout the 
flume were designated as check points to assess the calibration solution (Chandler, 1999).

All photogrammetric processing was completed in Leica Photogrammetry Suite (LPS) v9.1 (Leica, Wetzlar, Germany). The optimal settings for photogrammetric restitution were derived through iterative testing in LPS. The accuracy of the triangulation routine was assessed by comparing the objectcoordinate and image-coordinate residuals generated by LPS (Chandler et al., 2001). These residuals represent the root-mean-square-error ( $r m s e$ ) of the GCPs and indicate the change between input coordinates (object space) and the newlyestimated coordinates derived from the triangulation routine. The rmse for the GCPs was $<0.7 \mathrm{~mm}$ (X, Y, Z directions) and $<0.7 \mu \mathrm{m}$ in the object space and image space, respectively, combining a 2D camera calibration model in LPS with an external camera calibration (Chandler et al., 2005; Chandler \& Clark, 1992 - GAP calibration). Orthophotographs and DEMs were generated from alternate image pairs (Wackrow et al., 2008).

\section{Digital Elevation Models (DEMs)}

The pixel cell resolution of the output DEMs was $3 \times 3 \mathrm{~mm}$. Error assessments were made on the DEMs following routines similar to those described by Brasington \& Smart (2003), Chandler et al. (2005), and Wackrow et al. (2008). Digital elevation model accuracy was assessed using the residuals of the input GCP elevations and the modelled GCP elevations (e.g. Brasington \& Smart, 2003). An independent estimate of precision was made by comparing the elevations of 60 paired-points from regions known to have no change between DEM epochs. Internal reliability was assessed by 
measuring the elevation at points on different image-pairs that covered the same area (e.g. Pyle et al., 1997). Based on these error assessments, the output DEMs had an accuracy of $2 \mathrm{~mm}( \pm 1.3 \mathrm{~mm})$, internal reliability was $1 \mathrm{~mm}$ and vertical change detection accuracy was $\pm 3 \mathrm{~mm}$ which is equivalent to $\mathrm{D}_{90}$ of the flume sediment.

Perspective errors tend to be most common at the periphery of vertical images (Wolf \& Dewitt, 2000) and for this reason GCPs at the periphery of the images were excluded and all analysis was completed on a cropped DEM template. The individual cropped DEMs were assembled in ERDAS Imagine to generate DEM mosaics of a 2.5 x $10 \mathrm{~m}$ section of the physical model (Fig. 3B).

During the 41 hours of experiment time the bed elevation varied over a range of values at each location. From the minimum and maximum values at each point two specific surfaces are defined here: the minimum surface and the maximum surface denoted by the lowest and highest elevations at each point during the 41 hours of experiment time. The difference between these two surfaces over the areal extent of the data has been referred to as the morphological active layer (Leduc et al., 2015) and below it is used to assess deposit thickness in the active channel between highest braid bar surfaces and the lower channel and scour elevations.

\section{Orthophotographs}

Digital elevation models (DEMs) generated from the photogrammetric restitution were used to generate the orthophotographs (Fig. 3A). True accuracy of the orthophotographs was determined by comparing the measured distance between 
GCPs in the river model to the same points measured on the orthophotographs. This analysis indicated that the mean accuracy of the orthophotographs was $0.7 \mathrm{~mm}( \pm$ $0.5 \mathrm{~mm})$.

\section{Grain Texture Maps}

River bed grain texture information was derived from the vertical images using an empirical predictive relationship between image texture properties and surficial grain size. The basis of the approach is described in Carbonneau et al. (2005a) and Carbonneau (2005b), where local image texture properties were derived from a 64 grey-level co-occurrence matrix (Haralick et al., 1973) and correlated to samples of homogeneous bed-surface grain patches. Extensive calibration and parameter testing improved the accuracy and reliability of the textural analysis and mapping (see Leduc et al. 2015). The sampling window was 7 x 7 pixels (chosen based on median grain size and image resolution) and the best fit of the data was based on the entropy index. Calibration was developed by sampling small patches of grains on the model surface using adhesive. The samples were then physically sieved to derive the patch grain size statistics. Fifty-eight patches had uniform grain size and an additional 152 samples randomly distributed across the surface had the full range of grain sizes and gradations. Half of the samples were used to develop the calibration and the other half to validate the calibration and derive error statistics (see Leduc et al., 2015, fig. 1). The mean absolute error of the median grain size of a patch was $0.38 \mathrm{~mm}$, standard deviation was $0.61 \mathrm{~mm}$. The relative error of the absolute grain size ranged from o to $100 \%$ but over half of the calibration set had an error less than $20 \%$. The derived data are image-based grain-size estimates of the median grain size, not strictly physically-measured grain sizes (Leduc et al., 2015). Maps of this grain size were produced in Scilab ${ }^{\circledR}$ using the ortho-rectified output images and mosaicked into 
a continuous map for each time period (Fig. $3 \mathrm{C}$ ). Very clear particle size sorting is apparent throughout the runs with patterns very similar to those observed in the field (for example, lateral sorting in bends and confluences, bar head coarsening, longitudinal sorting on bars) (Leduc et al., 2015) (Fig. 4).

\section{RESULTS}

\section{Channel morphology and dynamics}

The intent of the analysis is to relate deposit and maximum $/$ minimum surface geometry to the river morphology and processes of morphological change (scour, bar formation, migration, avulsion). Therefore this section begins with a short description of the morphological changes over the 41 hour analysis period. These morphological changes and associated sediment sorting patterns can be viewed in the time lapse animations of DEMs and grain maps included with the additional material for the paper.

The experiment was initiated from a straight channel with a trapezoidal crosssection ( $1.5 \mathrm{~cm}$ deep, $50 \mathrm{~cm}$ wide) and a braided morphology self-formed within a few hours. The braided morphology persisted and was constantly active for the remainder of the experiment. At the beginning of the observation period, after over 130 hours of braiding activity, the river had reworked the entire model area and had a fully-developed and active braided morphology. During the subsequent 41 hours, the main channel underwent considerable morphological changes; anabranch confluences were formed and abandoned, new bars were deposited and there was one major avulsion of the main channel. However, some areas of the flume had no measurable elevation change due to inactive channels occupying the area during the 
sampled period. These 'no change' areas constitute about 30\% of the measured area and are mainly large, stable braid bars; they were removed from the analysis.

At the start of the observation period a single main active channel (an active channel is defined as one showing measurable morphological change over time, see Egozi \& Ashmore, 2009; Ashmore et al., 2011) was established on the right-hand side of the flume at the upstream end of the study reach. A single dominant active anabranch, with a larger number of inactive (or less active) channels appears to be characteristic of many gravel-bed braided rivers (Ashmore, 2013). This channel extended obliquely downstream and across the flume to join a large, formerly active, channel on the left side. A number of well-developed braid bars and secondary channels developed but only one secondary channel showed significant morphological change during the observation period. This active secondary channel originated at a persistent bifurcation area near the middle of the observed area, flowed along the right side of the flume in the downstream part of the observation area and remained partially active throughout the observation period undergoing local scour, fill, bar development and lateral migration. This relatively low active braiding intensity at any particular time is typical for proximal braided channels (Bertoldi et al., 2009; Egozi \& Ashmore, 2009; Ashmore et al., 2011). In the last one or two hours of the observations this channel became the route for a major avulsion and re-configuration of the channel pattern. Anabranch sinuosity was less than 1.05. This planform differs from the higher sinuosity main channel with systematic lateral migration and chute cutoffs analyzed by van de Lageweg et al. (2013a).

Morphological activity was focused around the zone of the main active anabranch which underwent significant morphological change. This includes: formation and abandonment of confluences with other anabranches and around new 
braid bars developed within the active channel zone; formation of lateral bars; midchannel bar formation and bifurcation around new bars; formation and abandonment of several active secondary branches; partial avulsions (Egozi \& Ashmore, 2009) and a major avulsion in the last two hours of the time period. Egozi \& Ashmore (2009, figs 6 to 10) show examples of channel and planform dynamics during another experiment in the same flume at the same slope and discharge as the current experiment.

\section{Maximum and Minimum Surfaces of Braided River Deposit}

The sequence of 41 hourly DEMs was analyzed to determine the evolution of the river and the topography of the maximum and minimum (upper and lower) surfaces of the deposit. Maximum and minimum surface maps were derived by overlaying all DEMs to extract the highest and lowest elevation value for each pixel from the 41 DEMs. The resulting maximum and minimum boundary surfaces are topographically distinct (Fig. 5A and 5B) and are easily differentiated from one another and from typical bed topography, based on the frequency distributions of their surface elevations (Fig. 6).

The minimum surface shows the channel features typical of a braided river, where areas of maximum scour are associated with, for example, erosion by the larger anabranches, scour in bends and confluences, and lateral migration or avulsion of anabranches and larger channels. The maximum boundary surface is also defined by a distinct morphology characterised by the amalgamation of individual bars, the cumulative geometry of major braid bar surfaces and the overall bar elevations along the river. Cross-sections of the minimum and maximum surfaces at 
2.33 $\mathrm{m}, 6.33 \mathrm{~m}$ and $9.93 \mathrm{~m}$ demonstrate the considerable differences in relief across the two surfaces (Fig. 7).

The maximum differences in elevation between the maximum and minimum surfaces occur at locations of greater channel activity (for example, cross-sections at $6.33 \mathrm{~m}$ and $9.93 \mathrm{~m}$ ). The profile at $6.33 \mathrm{~m}$ shows the large difference between the surfaces at a cross-section as a result of channel activity. The small difference at the left of the profile is indicative of an area of very minor topographic change while the much wider differences to the right results from substantial channel erosion and fill. Differences in the elevation distributions for the two surfaces can also be described using simple frequency distributions. Elevations overlap to a small extent because higher elevations in the minimum surface are the bases of minor channels which may be higher than some bar tops or other features in the maximum surface. The elevation distributions fit simple gamma distribution which aligns with observations of van de Lageweg et al. (2013b). The maximum surface distribution is narrower than that of the minimum surface because the latter reflects channel and bed topography while the former reflects primary bar top elevations which have an upper limit in elevation (Fig. 8).

Gardner \& Ashmore (2011) showed that by determining the time at which each pixel reached its minimum value it is possible to map the 'age' of the surface. This map shows that distinct tracts of the surface develop at different times, tied directly to the channel geometry and kinetics, with no systematic age pattern across the surface. The surface is formed by channel avulsion with very limited systematic lateral migration and bar accretion. In this way the formation of the braided river minimum surface differs from the more-systematic lateral channel migration of a 
meandering channel or chute-dominated higher-sinuosity braiding (van de Lageweg et al., 2013a,b). The minimum surface is not sub-planar and is not formed by continuous lateral planation.

\section{Grain-size distribution of maximum and minimum surfaces}

The maximum and minimum surfaces have a similar range in grain size but different spatial patterns of grain-size variation. The maximum surface grain map shows a wide range of grain sizes tied to the major bar features with patchy patterns of fine and coarse grains (Bluck, 1979; Rice \& Church, 2010) (Fig. 9A). Coarser areas may be partially winnowed and reflect 'maturing' of the grain surface over time (Bluck, 1979; Ashworth et al., 1992). The grain patterns on the minimum surface grain map (Fig. 9B) reflect the more-organized channel topography of this surface (Fig. 6). Active areas of the bed show elongated coarse-grained and fine-grained elements mainly parallel to the channel margins. The minimum surface grain map shows no extensive patches of coarse-grained lag deposits and the grain-size population is very similar to that of the maximum surface (Fig. 9A). The main feature that distinguishes the two boundary surfaces is the configuration and shape of the textural units, which is determined by the channel morphology, and by the erosional and depositional processes at each surface. In addition, the grain-size distribution of the surfaces is almost identical to that of the river bed itself at any given time (Fig. 10). For example, a Kolmogorov-Smirnov test of the distributions gave $D$ statistics of 0.110 (time 179 versus maximum surface) 0.070 (time 179 versus minimum surface) and 0.060 (maximum surface versus minimum surface), all of which show no significant difference at alpha of 0.05. Thus, at the channel-reach scale, there is no 
statistical distinction between the grain-size distributions of the river bed, the minimum or the maximum surfaces (see also Leduc et al., 2015).

\section{Deposit Thickness}

The thickness of the deposit was computed by differencing the maximum and minimum surfaces, resulting in a DEM of difference that shows the deposit thickness above the minimum surface (Fig. 11). The maximum surface is, in effect, the timeintegrated floodplain elevation of the braid bar tops and associated channels (Rheinfelds \& Nanson, 1993). Subsequent reworking may erode parts of the higher surface so one can think of this as the maximum deposit thickness based on bed elevation information and perhaps not the 'true' deposit thickness depending on post-depositional changes. However, bar tops are the least likely areas to undergo subsequent erosion under the experimental conditions, except by lateral bar trimming. Maximum bed thickness of the deposit is $0.048 \mathrm{~m}$ (scales to $1.55 \mathrm{~m}$ at the prototype scale) and the mean deposit thickness is about $0.015 \mathrm{~m}$ (scales to $0.48 \mathrm{~m}$ ). Maximum thicknesses coincide with the main active channel belt. The distribution of thickness values shows a skewed distribution with a long tail towards higher thickness which follows a Gumbel distribution with a significance level of 0.01 for a Kolmogorov-Smirnov distribution test (Fig. 12).

The cumulative distribution demonstrates that only about $15 \%$ of the deposit is greater than $0.02 \mathrm{~m}$ (scales to $0.64 \mathrm{~m}$ in full scale river) in thickness. Based on measurements from the DEMs, the mean anabranch depth was about $0.015 \mathrm{~m}$ and the mean confluence depth was $0.023 \mathrm{~m}$. If channel depth approximates deposit thickness (Bridge, 2003; Lunt \& Bridge 2006; van de Lageweg et al., 2013b), then it 
appears that confluences make up a distinct part of the thickness distribution (see below). The areas of maximum thickness coincide with the areas of lowest elevation on the minimum surface map indicating that local scour processes and channel erosion, rather than channel aggradation or bar top elevations, controls the bed thickness at the channel-scale (Ashworth et al., 1999). Bed thickness reflects the channel-scale erosion below a low-relief maximum (depositional) surface formed by amalgamation of the surfaces of major braid bars. This control of bed thickness by basal erosion can be shown by plotting local deposit thickness against elevation for the maximum and minimum surface. There is a much stronger trend for deposit thickness with lower minimum surface elevation than with higher maximum surface elevation (Fig. 13).

\section{Confluences at the Minimum Surface}

The areas of channel confluence are often zones of deepest scour and maximum deposit thickness (Ashmore \& Gardner, 2008). This is a unique and potentially diagnostic feature of some braided river deposits (see Introduction). However, there are few, if any, quantitative data on the contribution of confluences to deposit geometry and minimum surface characteristics. The contribution of confluence scour to development of the minimum surface was assessed by mapping (manually) the time-integrated area of 31 confluences to identify those pixels in confluences that coincided with minimum surface elevations using the hourly paired DEMs and orthophotographs. Confluences have a very distinct and identifiable morphology (Ashmore \& Gardner, 2008; Fig. 4) so that the area of the confluence can be identified from the elevation data and visually in the DEMs. 
Upstream limits of confluences were defined by the upstream anabranch termination at the head of the confluence (often with an obvious negative step in bed elevation) and the downstream extent by the location at which channel depth returned to a depth similar to the upstream anabranches. Each confluence was mapped at hourly intervals by delineating the area of the confluence scour zone on the orthophotographs until the confluence was abandoned or filled in. Confluence elevation data were derived by overlaying the confluence area and DEM for each hour that the confluence existed. The portions of each confluence that formed the minimum surface were patched together and area and elevation data were derived.

Individual confluences occupy very small areas of the entire experimental river at a given time but if they exist for several hours the migration of the confluent channels may extend the area affected by confluence scour both laterally and longitudinally and cover a much larger area of the river cumulatively over time (Ashmore \& Gardner, 2008). Confluence angles ranged from 5 to 81 degrees; they form at an active anabranch confluence, develop with the changes in size, orientation and position of the confluent anabranches, and then become inactive and infilled when those anabranches shift location, at which point new confluences form in new locations (Fig. 14). Average life span of confluences was 5 hours, longitudinal migration length averaged about 1.4 times confluence length and lateral migration was typically 1 times confluence width. Migration direction was no more than plus/minus 30 degrees from the flume (river) long axis and typically much less, suggesting that lateral migration is very limited in most cases.

Based on these maps and associated data, confluences occupied approximately $21 \%$ of the active area of the river bed during the experiment (Fig. 14A) and about $5 \%$ of the area of the minimum erosion surface (Fig. 14B). Although the areal 
contribution of confluences to the minimum surface was small, confluences do have a consistent effect on the minimum surface because 26 of the 31 confluences [ 158 of 176 (90\%) confluence measurements] included in the analysis eroded to the minimum surface in at least part of their extent. This varies spatially and there are areas of denser, persistent confluence occurrence especially near the centre of the mapped channel area (Fig. 14).

\section{Confluence Deposit Thickness}

The confluence deposit thickness was derived by subtracting the minimum surface associated only with confluence zones from the maximum surface. The resulting map (Fig. 14C) shows the varying deposit thickness at each confluence, and that the deeper deposits generally coincide with the confluences that contributed the largest area to the minimum surface (compare with Fig. 14A and B).

The isolation of the confluence deposits and the relative lack of connection among the confluence deposits are striking. These spatial patterns are similar to outcrop interpretations of ancient braided rivers that have documented confluence deposits in isolated clusters (e.g. Cowan, 1991; Miall \& Jones, 2003). Figure 14C shows that the confluence deposits are distributed mainly along the main channel belt and are part of the main body of the deposit setting the maximum thickness of the strata associated with large scale braid bars and channel fills and are comparatively thicker than other portions of the river deposit (Fig. 15). Deposits not associated with confluences averaged $0.016 \mathrm{~m}$ thickness (which scales up to $0.38 \mathrm{~m}$ at the prototype scale), while confluence deposits averaged $0.022 \mathrm{~m}$ thickness (scales to $0.74 \mathrm{~m}$ at the prototype scale) (Table 1). Although confluences made up $5 \%$ of the total area of the minimum surface (Fig. 14C), the volumetric contribution of 
confluences to the deposit was $22 \%$, so that, because of the deposit thickness, confluence deposits make up a greater proportion of braided river deposits than their areal contribution to the minimum surface. There is overlap between the thicknesses of confluence and non-confluence deposits but confluence deposits make up a large proportion of the thicker deposits and almost all of the deposit thicknesses that exceed 0.035m (scales to $1.12 \mathrm{~m}$ equivalent to about 10 times $\mathrm{D}_{90}$ of the bed sediment) (Fig. 15).

\section{DISCUSSION}

The results of this quantitative analysis of proximal gravelly braided river deposit topography, geometry and particle size characteristics expands existing knowledge of this type of alluvium in several respects. By mapping river bed topography at braid bar and anabranch confluence-diffluence scales over time the minimum and maximum elevations of the surface at any location can be defined and combined into surfaces that define the topography of lower (erosion) surface and the upper (depositional) surface of the deposit. It retains substantial topography related to major channels, confluence scour and avulsion rather than systematic lateral migration. The locally variable time of formation of the basal surface (Gardner \& Ashmore, 2011) reflects these dynamics and the tendency for this type of lowsinuosity channel to undergo repeated local avulsion and cutoff rather than develop by extensive lateral migration and planation. The topography of the maximum surface differs from the minimum surface reflecting the merging of the tops of the major braid bars. This contrasting topography of the maximum and minimum surface, and the more symmetrical frequency distributions, differ from those in higher sinuosity channels with chute cutoffs (van de Lageweg et al., 2013, a,b). The 
observation that the minimum surface is not formed by progressive lateral migration of channels or confluence scour at the base of major braid bars differs from assumptions and descriptions for some braided rivers (Miall, 1977; Best \& Ashworth, 1997; Bridge \& Lunt, 2006; Best \& Rhoads, 2008). These differences may be related to different channel dynamics in differing river types. Documentation and further understanding these differences would aid future deposit interpretation and syntheses of braided river morpho-sedimentary characteristics.

The grain-size distribution is much wider than that used in some other physical model experiments (for example, $\mathrm{D}_{90} / \mathrm{D}_{10}$ of the bed material is about 15 compared to about 5 in van de Lageweg et al., 2013a) and is a geometrically-scaled representation of the gravel component of the alluvium in the full scale river on which the model is based (see Introduction and Fig 2). In this way, full median grain size sorting patterns of gravel are reproduced in the model and the grain size mapping here ties local grain sizes to bed elevation. Grain-size characteristics of the minimum and maximum surfaces are not statistically different. While there are some patches and strings of coarser material at the basal surface there is no extensive planar, coarsegrained base. This reflects the avulsive nature of the channels and the complex elevational sorting in this type of channel. It is consistent with classic field observations such as Boothroyd \& Ashley (1975) in proximal gravel braiding rivers. Grain size sorting patterns (for example, coarse or fine threads of particle size) at the basal surface follow the channel and major bar accretion orientations (Leduc et al., 2015) but at the maximum surface spatial grain sorting patterns are less obviously tied to the channel structure and orientation. Instead the sorting patterns at the maximum surface appear to reflect the amalgamation of bars or perhaps channels 
where sediment transport is no longer active. This absence of spatially-aggregated grain-size differences between the minimum and maximum surface gives quantitative support for previous observations of an overall absence of a general tendency for vertical grain-size differentiation within the channel (not overbank) deposits of gravelly braided alluvium (Boothroyd \& Ashley, 1975, fig. 25; Bluck 1979; Sambrook Smith, 2000; Heintz et al., 2003; Lunt \& Bridge, 2004; Lunt et al., 2004; Marren, 2005; Guerit et al, 2014). This is a result of complex spatial sorting so that, for example, coarse sediment may occur at high elevation at bar heads and at low elevations in channels, and bedload sheets may run up onto bar margins and tops. Finer particles occur at low elevation on bar tails, laterally in channels and confluences, and also higher on bar surfaces. Confluences are not necessarily areas of coarse lag (although local coarse deposits occur) because during formation they are areas of local peak bed shear stress and particle mobility and all particle sizes are mobile.

In the physical model, confluences form along the main channel belt, have a limited spatial extent and do not exhibit continuous, extensive migration either laterally or longitudinally. Migration is typically limited to one to one and a half times confluence dimensions. Over time, confluences form and fill in different locations, primarily in relation to local avulsion and 'partial avulsion' along the main channel belt, to cumulatively affect larger portions of the deposit than the individual confluences at any particular time. Confluence scour forms a relatively small proportional area of the basal erosion surface, but many of the confluences form at least part of that surface and are associated with the lowest elevations of the surface. Previous model and field comparisons for this type of braided river have confirmed the scaling of confluences (Ashmore \& Parker, 1993, Best \& Ashworth, 1997), and 
migration distances (scaled by river size) are similar to those reported by Best \& Ashworth (1997) for a very large braided river confluence. Contrary to previous speculation for some braided river confluences (Best \& Ashworth, 1997), confluences do not form extensive planation of the basal surface in this case. Field investigations of gravel braided river confluences over extended time periods are needed to confirm this finding. Large-scale scour and trough cross-bedding that is reported to comprise large proportions of some large-scale outwash deposits and interpreted to relate to confluence scour (Siegenthaler \& Huggenberger, 1993; Huggenberger \& Regli, 2006) may be the deposits of large scale distal braided rivers with extensive, multilobate, linguoid bars (Boothroyd \& Ashley, 1975) and therefore different in character from the proximal braided gravel channel modelled here.

Deposit thickness has a distinct distribution related primarily to channel geometry and erosion depth below the low relief maximum surface. Confluence scour is responsible for most of the thickest portions of the deposit and confluence areas have a higher average thickness than the non-confluence areas. This may also contribute to the heavier tail of the thickness distribution than the form associated with bedform and bar migration alone (Paola \& Borgman, 1991; Ganti et al., 2011; Straub et al., 2012; van de Lageweg et al., 2013b).The recognition of the role of confluences in deposit geometry extends previous work on models of gravely braided alluvium (Moreton et al., 2002; Lunt \& Bridge, 2004, Lunt et al., 2004; Marren, 2005; Bridge \& Lunt 2006) which depict confluence areas and fill but give no quantitative data of the kind derived in this study. Some further refinement of these deposit models may be useful, perhaps including confluences as an element of the primary channel fill (Moreton et al., 2002). Recent physical model experiments on deposit geometry van de Lageweg et al., (2013 a,b) comment that confluence erosion 
lowers the elevation of the basal surface and therefore affects maximum set thickness. The results here confirm and add to this observation. Confluence scour is the main component of the tail of the maximum thickness distribution and this may be a distinctive feature of the deposit geometry of some braided rivers. Combined with existing knowledge of confluence geometry (Ashmore \& Parker, 1983; Ashmore \& Gardner, 2008; Best \& Rhoads, 2008) this may be applied to interpretation and predictive analysis of deposits (van de Lageweg, 2013b).

The experiment covers a limited time period and an interesting issue is whether the contribution of confluence zones to deposit geometry would change with a longer time for re-working of the river. There is substantial overlap in deposit thickness between confluence and non-confluence deposits so that extended reworking and channel pattern dynamics may not increase the proportion of confluence deposit volume over time but at present this is unknown. This is a problem - along with the effect of flow variation on deposit geometry - that is ripe for numerical simulation of the type that has been done for sand-bed anabranching rivers (Nicholas et al., 2016) in which much longer periods of reworking could be easily achieved and for which physical model results could provide some initial validation.

The effects of varying discharge would be another useful research direction. Pro-glacial rivers have low variability in their peak flows and gravel-bed rivers are typically active only close to daily peak flow conditions. Examination of other flow regimes in which much higher peak flows are possible (for example, observations on Tagliamento River, Bertoldi et al, 2010) and the effects on planform and intensity geomorphological processes is likely to be reflected in deposit geometry and to be different from the proximal gravel case, and may provide contrasts with variable flow effects in sand-bed braiding (Nicholas et al., 2016). 
While the formative processes of confluence flow structure, morpho-dynamics, and sedimentology is well documented, the results of this study indicate confluence behavior in these types of braided rivers and possibly confluences in larger river networks, may demonstrate scale-invariance.

\section{CONCLUSIONS}

A Froude-scaled physical model of a proximal gravel braided river was used to quantitatively characterize the geometry and grain-size characteristics of the river deposit from sequential digital elevation data and grain size maps of the model river bed. The data represent the sedimentary products of braid bar and anabranchconfluence-diffluence morphology and processes - the basic morphological building blocks of braided river morphology. The main conclusions are:

1. The minimum erosion surface has a greater range of elevation than the maximum deposition surface. The minimum surface has clear elements of channels and confluences while the maximum surface reflects the spatio-temporal integration of braid bar tops. Spatially aggregated grain-size distributions of the minimum and maximum surface are indistinguishable, there is no extensive basal coarse layer and no general vertical sorting pattern of grain sizes.

2. A large proportion of anabranch confluence zones erode down to the minimum surface although they do not form the bulk of the area of the minimum surface over the time span of the experiment. Anabranch confluences show only limited migration equivalent to up to 1.5 times the confluence dimensions. The minimum surface is not formed by extensive lateral migration but by avulsion, 
channel and confluence scour, and limited lateral channel development. This is consistent with the known morphology and dynamics of this type of river.

3. Deposit thickness is determined mainly by the elevation of the minimum surface rather than the height of the depositional bar tops and maximum thickness is determined by confluence depths. Confluences form the thickest portion of the deposits.

\section{ACKNOWLEDGEMENTS}

Funding was provided by a Natural Sciences and Engineering Research Council Discovery Grant to Peter Ashmore and flume construction was supported by the Canada Foundation for Innovation and Newalta Resources. We thank Jim Chandler and Rene Wackrow for their support in applying the photogrammetric methods. Several people assisted with the experiments, especially Roey Egozi and Beth Hundey. Chris Hugenholtz provided the UAV imagery used in Fig. 1B. Comments on a previous version by Greg Sambrook Smith, Arjan Reesink and Vern Manville helped us to clarify important points and improve the presentation. 


\section{REFERENCES CITED}

Ashmore, P.E. (1982). Laboratory modelling of gravel braided river morphology, Earth Surf. Proc. Land., 7, 201-225.

Ashmore, P.E. (1993). Anabranch confluence kinetics and sedimentation processes in braided streams. In: J.L. Best and C. Bristow (eds.), Braided Rivers: form, process and economic applications, Geological Society Special Publication $\mathbf{7 5}$, 129-146.

Ashmore, P. (2013) Morphology and dynamics of braided rivers. In: Treatise on Geomorphology (Eds. J. Shroder and E. Wohl. Academic Press, San Diego, CA vol. 9, Fluvial Geomorphology, pp 289-312.

Ashmore, P.E. and Gardner, J.T. (2008) Unconfined confluences in braided rivers. In: River confluences, tributaries and the fluvial network (Eds S. Rice, A. Roy, B.L. Rhoads), pp. 119-148. Wiley Publications, London.

Ashmore, P.E. and Parker, G. (1983) Confluence scour in coarse braided streams. Water Resour. Res., 19, 392-402.

Ashmore, P. Bertoldi, W. and Gardner, J.T. (2011) Active width of gravel-bed braided rivers. Earth Surf. Proc. Land., 36, 1510-1521. DOI: 10.1001:esp2182

Ashworth, P.J. Ferguson, R.I. Ashmore, P.E. Paola, C. Powell, D.M. and Prestegaard, K.L. (1992) Measurements in a braided river chute and lobe 2: Sorting of bed load during entrainment, transport, and deposition. Water Resour. Res., 28, 1887-1896. 
Ashworth, P.J. Best, J.L. Peakall, J. and Lorsong, J.A. (1999) The influence of aggradation rate on braided alluvial architecture: field study and physical scale modeling of the Ashburton River gravels, Canterbury plains, New Zealand. In: Fluvial Sedimentology VI (Eds N.D. Smith and J. Rogers) Blackwell IAS Publication, 28, 333-346.

Bentham P.A., Talling, P.J. and Burbank, D.W. (1993) Braided stream and flood-plain deposition in a rapidly aggrading basin: the Escanilla formation, Spanish Pyrenees. In: Braided Rivers. (Eds J.L. Best and C.S. Bristow) Geological Society 75, 177-194.

Bertoldi, W., Zanoni, L. and Tubino, M. (2009). Planform dynamics of braided streams. Earth Surface Processes and Landforms, 34, 547-557.

Bertoldi, W., Zanoni, L. and Tubino, M. (2010). Assessment of morphological changes induced by flood pulses in a gravel bed braided river: The Tagliamento River (Italy). Geomorphology, 114, 248-360.

Best J.L. and Ashworth, P.J. (1997) Scour in large braided rivers and the recognition of sequence stratigraphic boundaries. Nature, $\mathbf{3 8 7}$, $275-277$.

Best, J.L. and Rhoads, B.L. (2008) Sediment transport, bed morphology and the sedimentology of river channel confluences. In: River confluences, tributaries and the fluvial network (Eds S. Rice, A. Roy, B.L. Rhoads), pp. 45-72. Wiley Publications, London.

Bluck, B.J. (1974) Structure and directional properties of some valley sandur deposits in southern Iceland. Sedimentology, 21, 533-554. 
Bluck, B.J. (1979) Structure of coarse grained braided stream alluvium. Trans. Roy. Soc. Edinburgh, 7o, 181-221.

Boothroyd J.C. and Ashley, G.M. (1975) Process, bar morphology and sedimentology structures on braided outwash fans, northeastern Gulf of Alaska. In: Glaciofluvial and Glaciolacustrine Sedimentation. (Eds A.V. Jopling and B.C. McDonald). SEPM Spec. Publ. 23, 193-222.

Brasington, J. and Smart, R.M.A. (2003) Close range digital photogrammetric analysis of experimental drainage basin evolution. Earth Surf. Proc. Land. 28, 231-247, doi:10.1002/esp.480.

Bridge J.S. (1993) The interaction between channel geometry, water flow, sediment transport and deposition in braided rivers. In: Braided Rivers (Eds J.L. Best and C.S. Bristow) Geological Society, 75, 13-72.

Bridge, J.S. (2003) Rivers and Floodplains: Oxford, Blackwell, 504 pp.

Bridge, J.S. and Lunt, I.A. (2006) Depositional models in braided rivers. In: Braided Rivers: Process, Deposits, Ecology and Management. (Eds J. L. Best, G.H. Sambrook-Smith, C. S. Bristow, and G. E. Petts), IAS, 36, 11-50.

Bristow C.S Best, J.L. and Roy, A.G. (1993) Morphology and facies models of channel confluences. In: Alluvial Sedimentation. (Eds M Marzo and C Puigdefabregas) $I A S$, 17, 91-100.

Carbonneau, P.E. Bergeron, N.E. and Lane, S.N. (2005a) Automated grain size measurements from airborne remote sensing for long profile measurements of fluvial grain sizes. Water Resour. Res., 41, W11426, doi:10.1029/2005WRo03994. 
Carbonneau, P.E. Bergeron, N.E. and Lane, S.N. (2005b) Texture-based image segmentation applied to the quantification of superficial sand in salmonid river gravels. Earth Surf. Proc. Land., 30, 121-127, doi:10.1002/esp.1140.

Chandler, J.H. (1999) Effective application of automated digital photogrammetry for geomorphological research. Earth Surf. Proc. Land., 24, 51-63, doi:10.1002/(SICI)1096-9837(199901)24:1<51::AID-ESP948>3.0.CO;2-H.

Chandler J. and Clark, J. (1992) The archival photogrammetry technique: further application and development. Photog. Rec., 14, 241-247.

Chandler J. Shiono, K. Rameshwaren, P. and Lane, S. (2001) Measuring flume surfaces for hydraulics research using a Kodak DCS460. Photog. Rec., 17, 39-61.

Chandler J. Fryer, J.G. and Jack, A. (2005) Metric capabilities of low-cost digital cameras for close range surface measurement. Photog. Rec., 20, 1226.

Church M. and Gilbert, R. (1975) Proglacial fluvial and lacustrine sedimentation. In: Glaciofluvial and Glaciolacustrine Sedimentation. (Eds A.V. Jopling, and B.C. McDonald). SEPM Spec. Publ., 23, 22-100.

Cowan E.J. (1991) The large-scale architecture of the fluvial Westwater Canyon member, Morrison formation (Upper Jurassic), San Juan Basin, New Mexico. In: The 3- dimensional facies architecture of Terrigeneous clasitc sediments and its implications for hydrocarbon discovery and recovery. (Eds A.D. Miall and N Tyler). SEPM, 80-93.

Egozi, R. and Ashmore, P. (2008) Defining and measuring braiding intensity. Earth Surf. Proc. Land., 22, 2121-2138. 
Egozi, R. and Ashmore, P. (2009) Experimental analysis of braided channel pattern response to increased discharge. J. Geophys. Res., 114, Fo2012, doi:10.1029/2008JFo01099

Ganti, V. Straub, K.M. Foufoula-Georgiou, E. Paola, C. (2011) Space-time dynamics of deposition systems: Experimental evidence and theoretical modeling of heavy-tailed statistics. J. Geophys. Res., 116, Fo211, doi:10.1029/2010JFo01893.

Gardner, J.T. (2009) Morpho-dynamics and sedimentology of confluences in gravelly braided rivers. PhD Thesis. University of Western Ontario.

Gardner, J.T. and Ashmore, P.E. (2011) Geometry and grain size characteristics of the basal surface of a braided river deposit. Geology, 39(3), 247-250, doi: 10.1130/G31639.1

Guerit, L. Barrier, L. Narteau, C. Métivier, F. Liu, Y. Lajeunesse, E. Gayer, E. Meunier, P. Malverti, L. and Ye, B. (2014) The Grain-size Patchiness of Braided Gravel-Bed Streams-example of the Urumqi River (northeast Tian Shan, China). Adv. Geosci., 37, 27-39.

Haralick, R.M. Shanmugan, K. and Dinstein, I. (1973) Textural features for image classification. IEEE Trans. Systems, Man and Cybernetics, 3, 610-621.

Hein, F.J. and Walker, R.G. (1977) Bar evolution and development of stratification in the gravelly, braided Kicking Horse River. British Columbia. Can. J. Earth Sci., 14, 562-570.

Heinz, J. Kleineidam, S. Teutsch, G. and Aigner, T. (2003) Heterogeneity patterns of Quaternary glaciofluvial gravel bodies (S-W Germany): Application to hydrogeology. Sed. Geol., 158, 1-23. 
Huggenberger, P. and Regli, C. (2006). A sedimentological model to characterize braided river deposits for hydrogeological applications. In: Sambrook Smith, G.H., Best, J.L., Bristow, C.S., and Petts, G.E. (Editors), Braided Rivers: Process, Deposits, Ecology and Management. International Association of Sedimentologists Special Publication, 36, 51-74.

Klaassen, G.J. and Vermeer, K. (1988) Confluence scour in large braided rivers with fine bed material. In: Proc. Intl. Conf. Fluvial Hydraulics, 395-408.

Kleinhans, M.G. and van den Berg, J.H. (2011) River channel and bar patterns explained and predicted by an empirical and a physics-based method. Earth Surf. Proc. Land., 36, 721-738, doi:10.1002/esp.2090

LeClair, S.F. Bridge, J.S. and Wang, F. (1997) Preservation of cross-strata due to migration of subaqueous dunes over aggrading and non-aggrading beds: comparison of experimental data with theory. Geoscience Canada, 24, 55-66.

Leddy, J.O., Ashworth, P.J., and Best, J.L. (1993). Mechanism of anabranch avulsion within gravel braided rivers: observations from a scaled physical model. In: J.L. Best and C. Bristow (eds.), Braided Rivers: form, process and economic applications, Geological Society Special Publication 75, 119-127.

Leduc, P. Ashmore, P. and Gardner, J.T. (2015) Grain sorting in the morphological active layer of a braided river physical model. Earth Surf. Dynamics, 3, 577-585, doi:10.5194/esurf-3-577-2015.

Lunt, I.A. and Bridge, J.S. (2004) Evolution and deposits of a gravelly braid bar, Sagavanirktok River, Alaska. Sedimentology 51, 415-432. 
Lunt, I.A. Bridge, J.S. and Tye, B. (2004) A quantitative, three-dimensional depositional model of gravelly braided rivers. Sedimentology, 51, 377-414, doi:10.1111/j.1365-3091.2004.00627.x.

Marren, P.M. (2005) Magnitude and frequency in proglacial rivers: A geomorphological and sedimentological perspective. Earth-Sci. Rev., 7o, 203251.

McDonald, B.C. and Banerjee, I. (1971) Sediments and bed forms on a braided outwash plain. Can. J. Earth Sci., 8, 1282-1301.

Miall, A.D. (1977) A review of the braided river depositional environment. EarthSci. Rev., 13, 1-62.

Miall, A.D. (2014) Fluvial Depositional Systems. Springer,Switzerland. 316 pp.

Miall, A.D. and Jones, B.G. (2003) Fluvial architecture of the Hawksbury sandstone (Triassic), near Sydney, Australia. J. Sed. Res., 73, 531-545.

Moreton, D.J. Ashworth, P.J. and Best, J.L. (2002) The physical scale modeling of braided alluvial architecture and estimation of subsurface permeability. Basin Research, 14, 265-285, doi:10.1046/j.13652117.2002.00189.x.

Nicholas, A.P., Sambrook Smith,G.H., Amsler, M.L., Ashworth,P.J.,Best, J.L., Hardy, R.J., Lane, S.N., Orfeo, O., Parsons, D.R., Reesink, A.J.H., Sandbach, S.D., Simpson, C.J., and Szupainy, R.N. (2016). The role of discharge variability in determining alluvial stratigraphy. Geology, 44, 3-6.

Paola, C. and Borgman, L. (1991) Reconstructing random topography from preserved stratification. Sedimentology, $\mathbf{3 8}, 553-565$. 
Paola, C. Straub, K. Mohrig, D. and Reinhardt, L. (2009) The "unreasonable effectiveness" of stratigraphic and geomorphic experiments. Earth-Sci. Rev., 97, 1-43.

Peakall, J. Ashworth, P. and Best, J.L. (1996) Physical modeling in fluvial geomorphology: Principles, applications and unresolved issues. In: The scientific nature of geomorphology (Eds B.L. Rhoads and C. E. Thorne) pp. 221-253. John Wiley and Sons, USA.

Pyle, C.J. Richards, K.S. and Chandler, J.H. (1997) Digital photogrammetric monitoring of river bank erosion. The Photogrammetric Record, 15, 753-764, doi:10.1111/0031-868X.00083.

Rheinfelds, I., and Nanson, G. (1993) Formation of braided river floodplains, Waimakariri River, New Zealand. Sedimentology, 40, 1113 - 1127.

Rust B.R. (1975) Fabric and structure in glaciofluvial gravels. In: Glaciofluvial and Glaciolacustrine Sedimentation (Eds A.V. Jopling and B.C. McDonald), SEPM Spec. Publ. 23, 238-248

Sambrook Smith, G.H. (2000) Small-scale cyclicity in alpine proglacial fluvial sedimentation. Sed. Geol., 132, 217-231.

Sambrook Smith, G.H. Ashworth, P.J. Best, J.L. Woodward, J. and Simpson, C.J. (2006) The sedimentology and alluvial architecture of the sandy braided South Saskatchewan River, Canada. Sedimentology, 53, 413434, doi:10.1111/j.1365-3091.2005.00769.x.

Sambrook Smith, G.H. Best, J.L. Ashworth, P.J. Lane, S.N. Porter, N.O. Lunt, I.A. Thomas, R.E. and Simpson, C.J. (2010) Can we distinguish 
flood frequency and magnitude in the sedimentological record of rivers? Geology, 38, 579-582, doi:10.1130/G30861.1.

Sheets, B.A. Hickson, T.A. and Paola, C. (2002) Assembling the stratigraphic record: depositional patterns and time-scales in an experimental alluvial basin. Basin Res., 14, 287-301.

Siegenthaler, C. and Huggenberger, P. (1993) Pleistocene Rhine gravel: deposits of a braided river system with dominant pool preservation. In: J.L. Best and C. Bristow (eds.), Braided Rivers: form, process and economic applications, Geological Society Special Publication, 75, 147-162.

Smith, N.D. (1974) Sedimentology and bar formation in the Upper Kicking Horse River, a braided outwash stream. J. Geol., 82, 205-223.

Steel R.J. and Thompson, D.B. (1983) Structures and textures in Triassic braided stream conglomerates ("Bunter" pebble beds) in the Sherwood Sandstone Group, North Staffordshire, England. Sedimentology, 3o, 341367.

Straub K.J. Ganti, V. Paola, C. Foufoula-Georgiou E. (2012) Prevalence of exponential bed thickness distributions in the stratigraphic record: Experiments and theory. J. Geophys. Res., 3o, Fo2003, doi:10.1029/2011JFoo2034.

Van de Lageweg, W. van Dijk, W.M. and Kleinhans M.G. (2013a). Morphological and stratigraphical signature of floods in a braided gravel-bed river revealed from flume experiments. J. of Sed. Res., 83, 1032-1045

Van de Lageweg, W. van Dijk, W.M. and Kleinhans M.G. (2013b). Channel belt architecture formed by a meandering river. Sedimentology 6o, 840-859 
Van Dijk, W.M. van de Lageweg, W.I. and Kleinhans M.G. (2013) Formation of a cohesive floodplain in a dynamic experimental meandering river. Earth Surf. Proc. Land., 38, 1550-1565

Van Dijk, W.M. van de Lageweg, W.I. and Kleinhans M.G. (2012) Experimental meandering river with chute cutoffs. J. Geophys. Res., 117, Fo3023

Wackrow, R. Chandler, J.H. and Gardner, T. (2008) Minimizing systematic errors in DEMs caused by an inaccurate lens model. The International Archives of the Photogrammetry, Remote Sensing and Spatial Information Sciences, 37, 1-6.

Williams, P.F. and Rust, B.R. (1969) Sedimentology of a braided river. J. Sed. Petrol., 39, 649-679

Wolf P.R. and DeWitt, B.A (200o) Elements of Photogrammetry, with applications in GIS. McGraw-Hill, New York, 6o8p.

Wooldridge, C.L. and Hickin, E.J. (2005) Radar architecture and evolution of channel bars in wandering gravel-bed rivers: Fraser and Squamish rivers, British Columbia, Canada: Journal of Sedimentary Research, v.75, p.844-86o, doi:10.2110/jsr.2005.066.

Young, W.J. and Warburton, J. (1996) Principles and practice of hydraulic modelling of braided gravel-bed rivers. J.Hydrol. NZ, 35, 175-198. 


\section{FIGURE CAPTIONS}

Figure 1 - (A) Example of an orthophotograph of the wetted river bed at hour 134 of the experiment; flow is left to right. (B) Orthophotograph of the model prototype river, Sunwapta River, Alberta, proximal location near the source; flow is left to right.

Figure 2 - Grain-size distribution curves of the flume river bed and an equivalent gravel bed river (Sunwapta River, Canada) used for scaling the model. Flume grainsize distribution is scaled at a 1:30 ratio to the Sunwapta River.

Figure 3 - (A) Orthophotograph; (B) digital elevation model (DEM); and (C) grainsize map of model river bed surface at time 179 of experiments.

Figure 4 - Examples of a channel confluence area in the model showing the major features, the visual delineation of the confluence area, and variable grain sorting. Arrows indicate flow direction, thick black lines are anabranch limits, thick dotted line is confluence scour zone and fine dotted line is zone of maximum scour depth; scale is approximate (flow is turned off).

Figure 5 (A) Minimum surface and (B) maximum surface digital elevation model (DEM) of the model river deposit. White areas in (A) are those that did not experience measurable bed elevation change. Cross-section locations [vertical lines in (B)] refer to Fig. 7. Vertical scale is normalized height from bottom of deposit and flow direction is left to right.

Figure 6 - Frequency distributions of maximum and minimum surfaces of braided river compared to elevation distribution of a single digital elevation model (DEM) (time 179 hours).

Figure 7 - Cross-sections of boundary surfaces. Profiles were taken at $2.33 \mathrm{~m}, 6.33 \mathrm{~m}$ and $9.93 \mathrm{~m}$ (local survey datum of flume) from left to right across surface (top to bottom on Fig. 5B).

Figure 8 - Gamma distribution fits to the elevation distributions of the maximum (A) and minimum (erosion) (B) surfaces.

Figure 9 - Boundary surface maps for: (A) maximum bed surface texture (grain size) map; and (B) minimum bed surface texture (grain size) map with no-change areas (white) removed. Texture scale is non-dimensional, higher numbers are coarser texture. Flow direction is left to right. 
Figure 10 - Equivalent texture (grain size) distribution for the minimum and maximum surface maps and experiment epoch 179 . Higher equivalent texture is coarser grain size.

Figure 11 - Deposit thickness digital elevation model (DEM); vertical (thickness) scale is in millimetres, white areas are no-change, flow direction is left to right.

Figure 12 - Deposit thickness distributions: Frequency distribution of deposit thickness (black line) and cumulative frequency distribution of deposit thickness (dotted line). Gumbel distribution fit to the thickness distribution.

Figure 13 - Relationship between deposit thickness and bounding surface elevation at minimum surface (A) and at maximum surface (B). There is a stronger tendency for deposit thickness to increase with lower minimum surface elevation than with higher maximum surface elevation.

Figure 14 (A) Initial locations of confluences, based on experiment time, and areas of bed elevation change. Grey areas are active bed areas with notable bed elevation change; white areas did not experience net change beyond change detection resolution; coloured areas are the time-integrated areas occupied by the 31 confluences analyzed. (B) Confluence areas, indicating migration patterns of the 31 confluences analyzed. (C) Time-integrated minimum surface of river deposit (after Gardner \& Ashmore, 2011) with overlay of confluence areas (black shaded areas) and confluence areas at the minimum surface (grey shaded areas), colour scale is experiment time in hours. (D) Confluence deposit thicknesses. Mean confluence deposit thickness is $0.022 \mathrm{~m}$. Vertical (thickness) scale is in millimetres, flow direction is left to right in all maps.

Figure 15 - Deposit thickness distributions. Data shown for overall deposit thickness (mean deposit), confluence deposit thickness (confluence deposits) and deposits not associated with confluences (non-confluence deposits). 


\section{Tables}

Table 1-Summary statistics of river deposits

\begin{tabular}{|c|c|c|}
\hline $\begin{array}{c}\text { Deposit } \\
\text { Thickness }\end{array}$ & $\begin{array}{c}\text { Non- } \\
\text { Confluence } \\
\text { Deposits }\end{array}$ & $\begin{array}{c}\text { Confluence } \\
\text { Deposits }\end{array}$ \\
\hline Mean (m) & 0.016 & 0.022 \\
\hline Median (m) & 0.016 & 0.021 \\
\hline Mode (m) & 0.016 & 0.021 \\
\hline St. Dev.(m) & 0.005 & 0.006 \\
\hline Volume (m) & 0.24 & 0.07 \\
\hline $\begin{array}{c}\text { \% Total } \\
\text { Volume }\end{array}$ & 77.8 & 22.2 \\
\hline
\end{tabular}



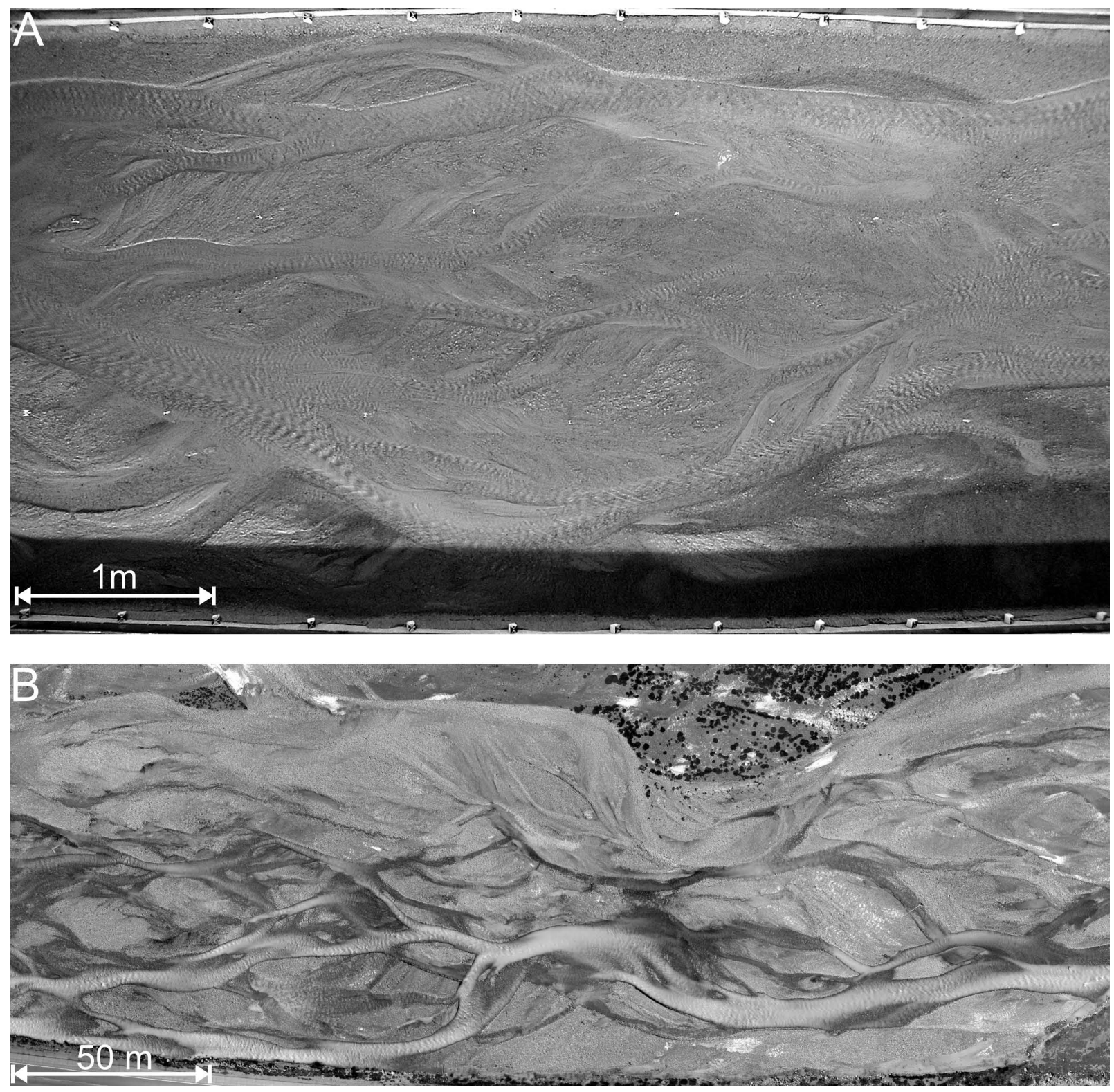

This article is protected by copyright. All rights reserved. 


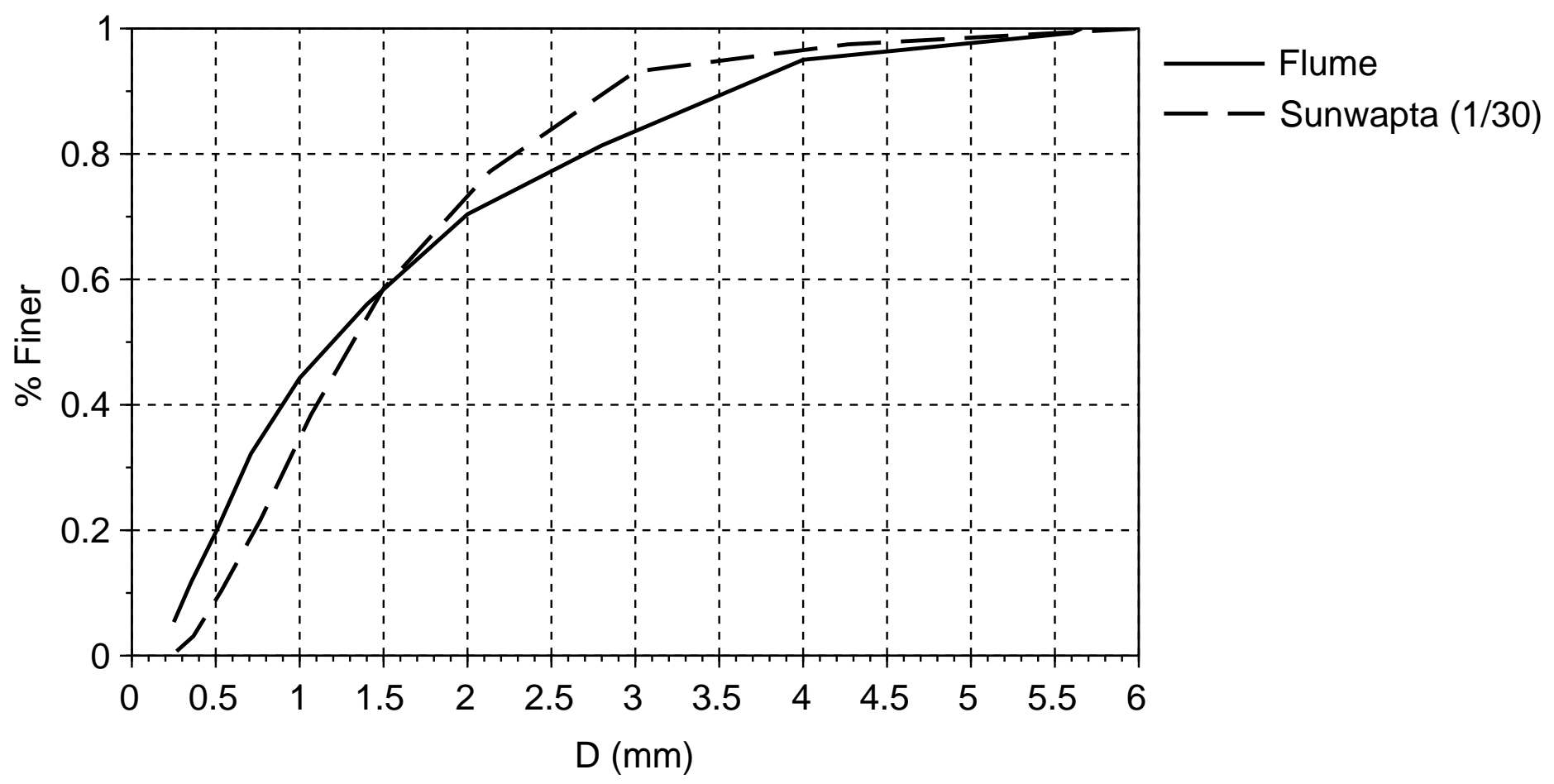

This article is protected by copyright. All rights reserved. 

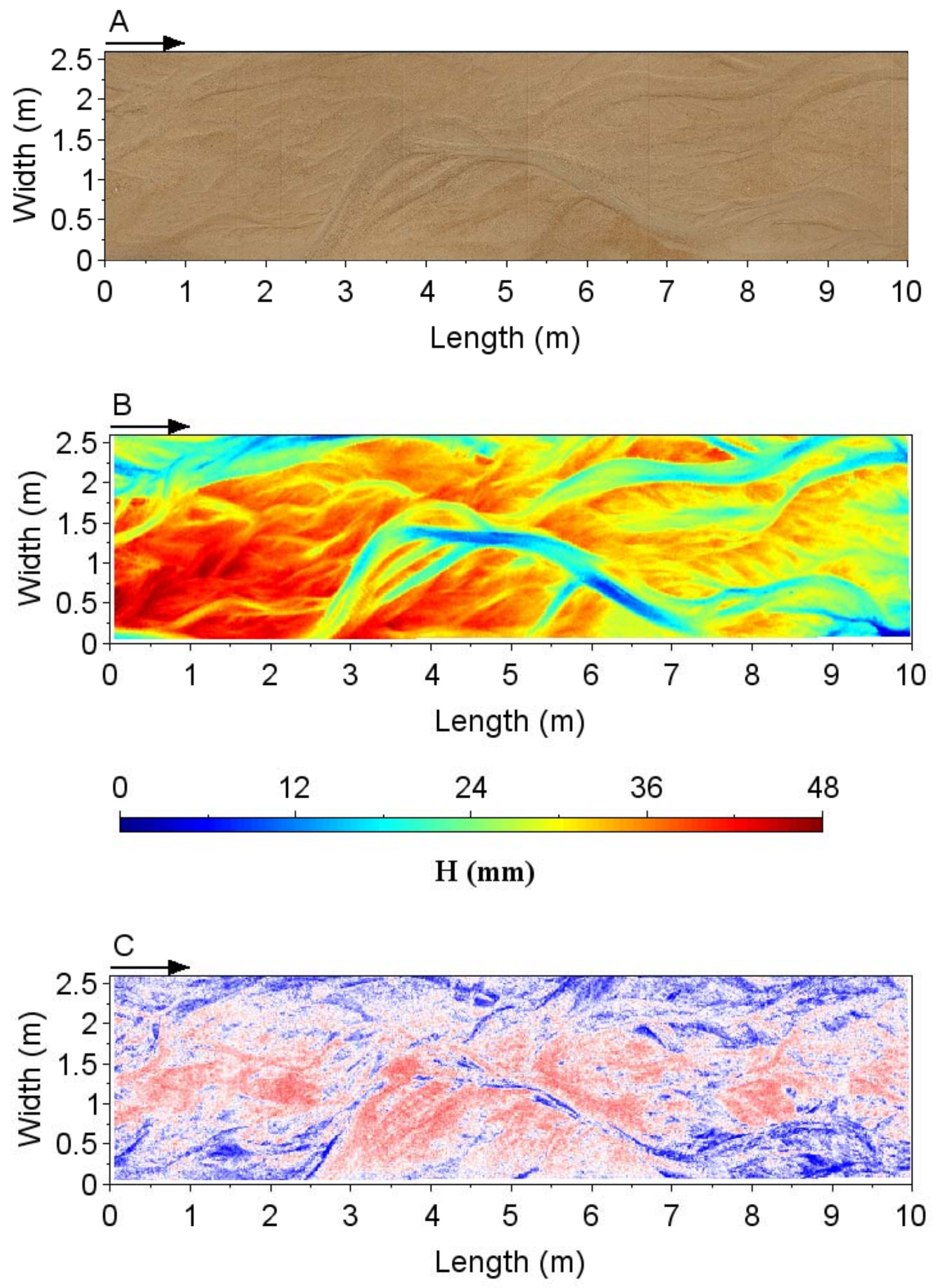

Fine

Median

Coarse

\section{Equivalent texture (-)}



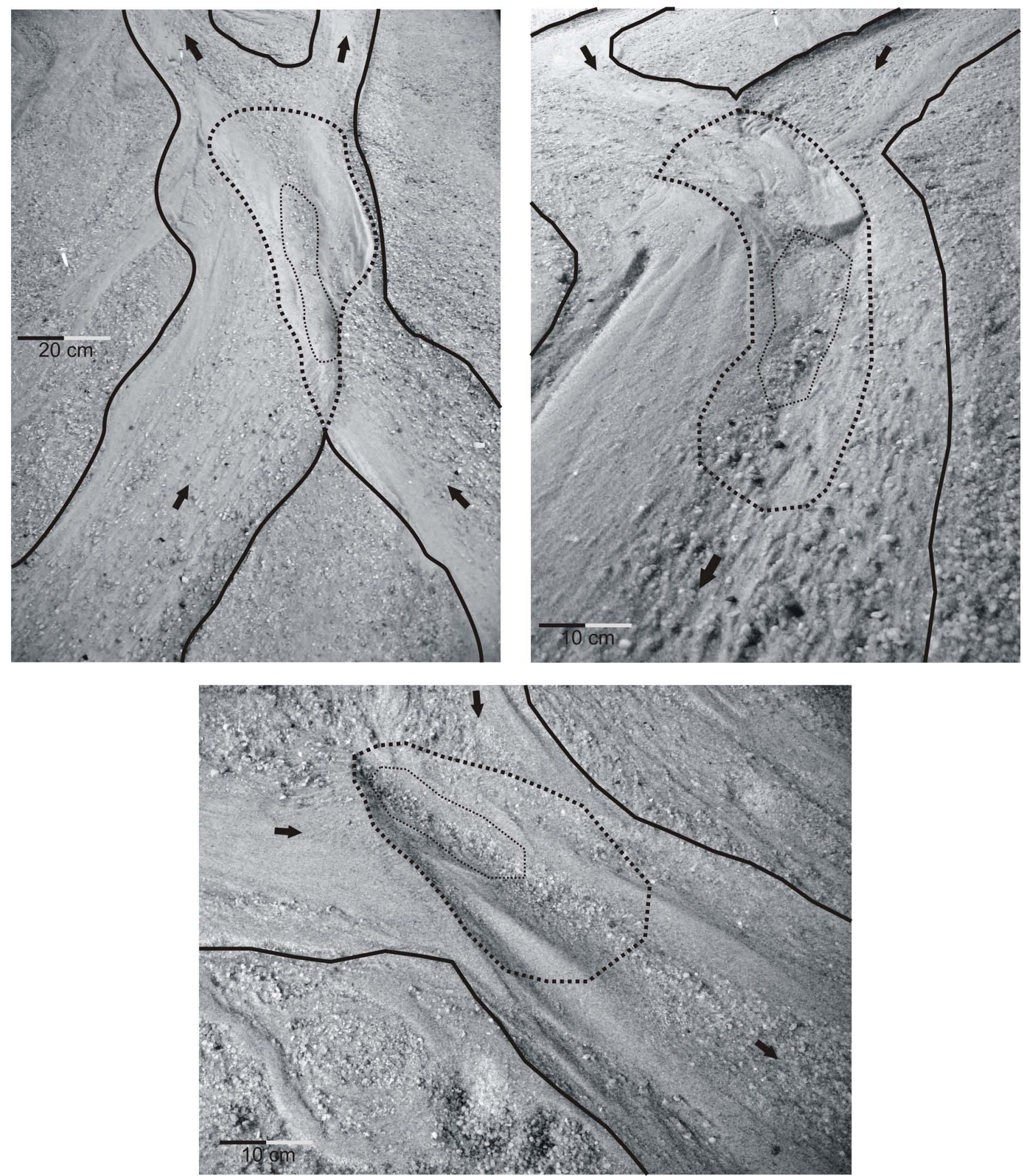

This article is protected by copyright. All rights reserved. 

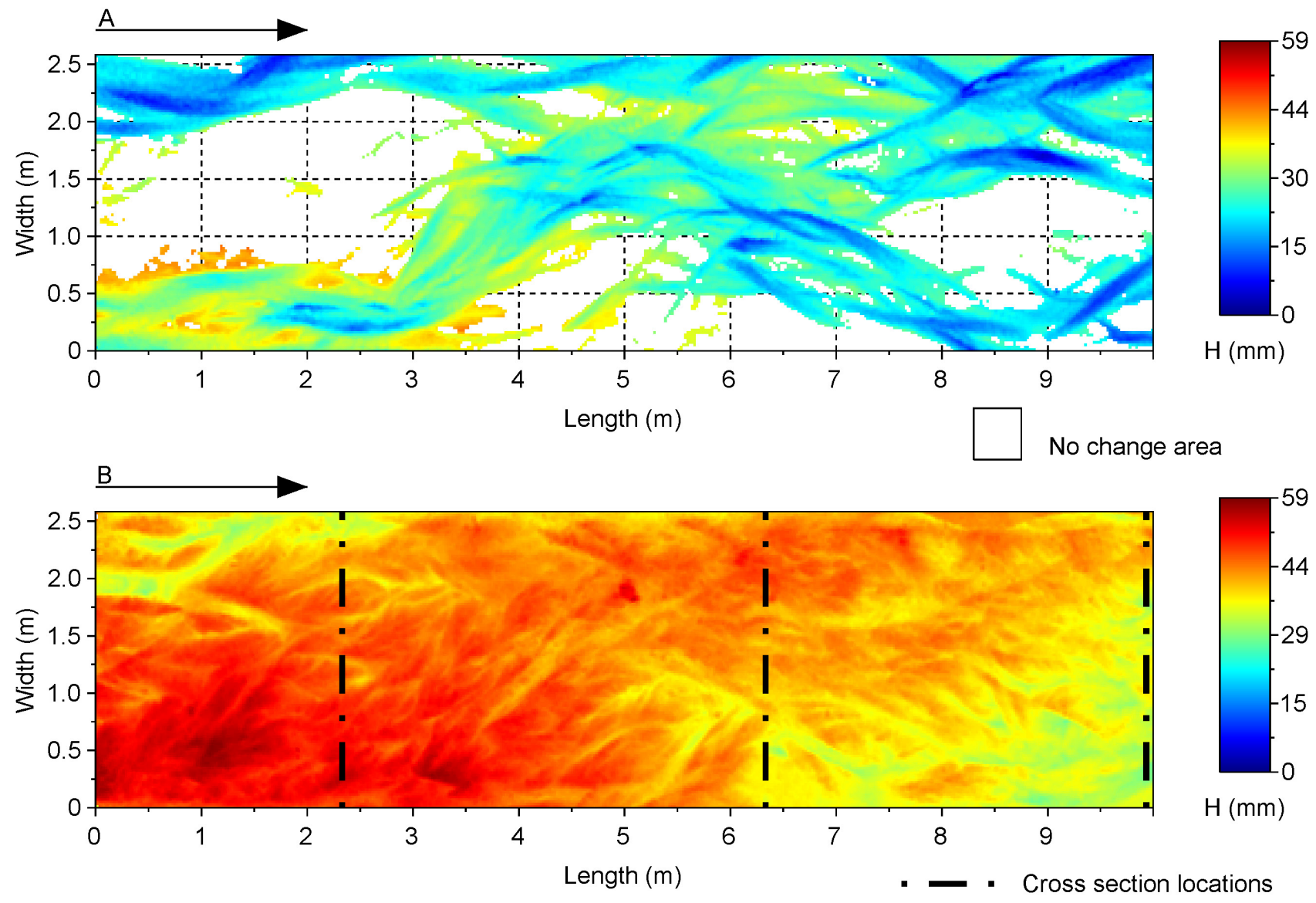

This article is protected by copyright. All rights reserved. 


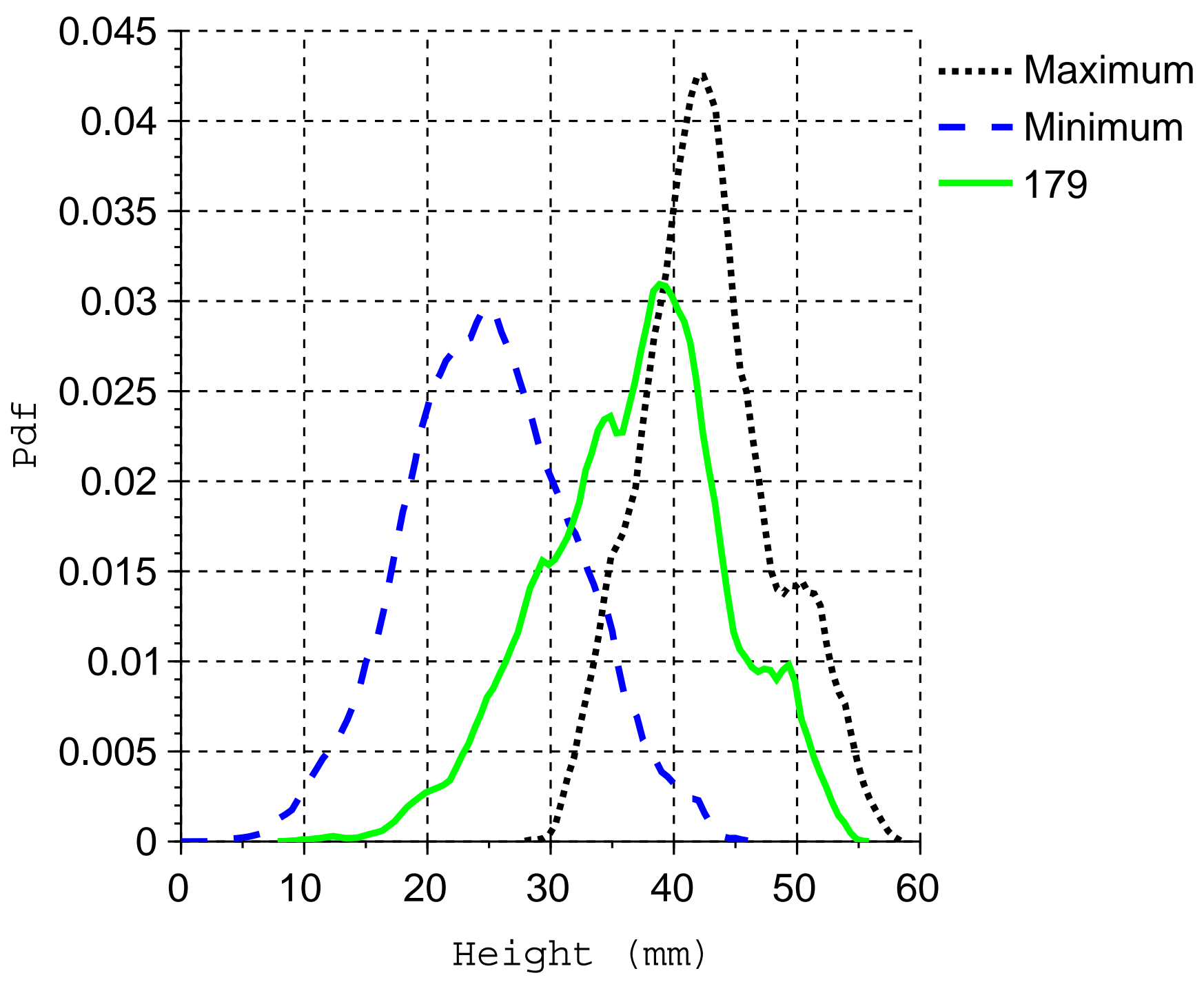

This article is protected by copyright. All rights reserved. 

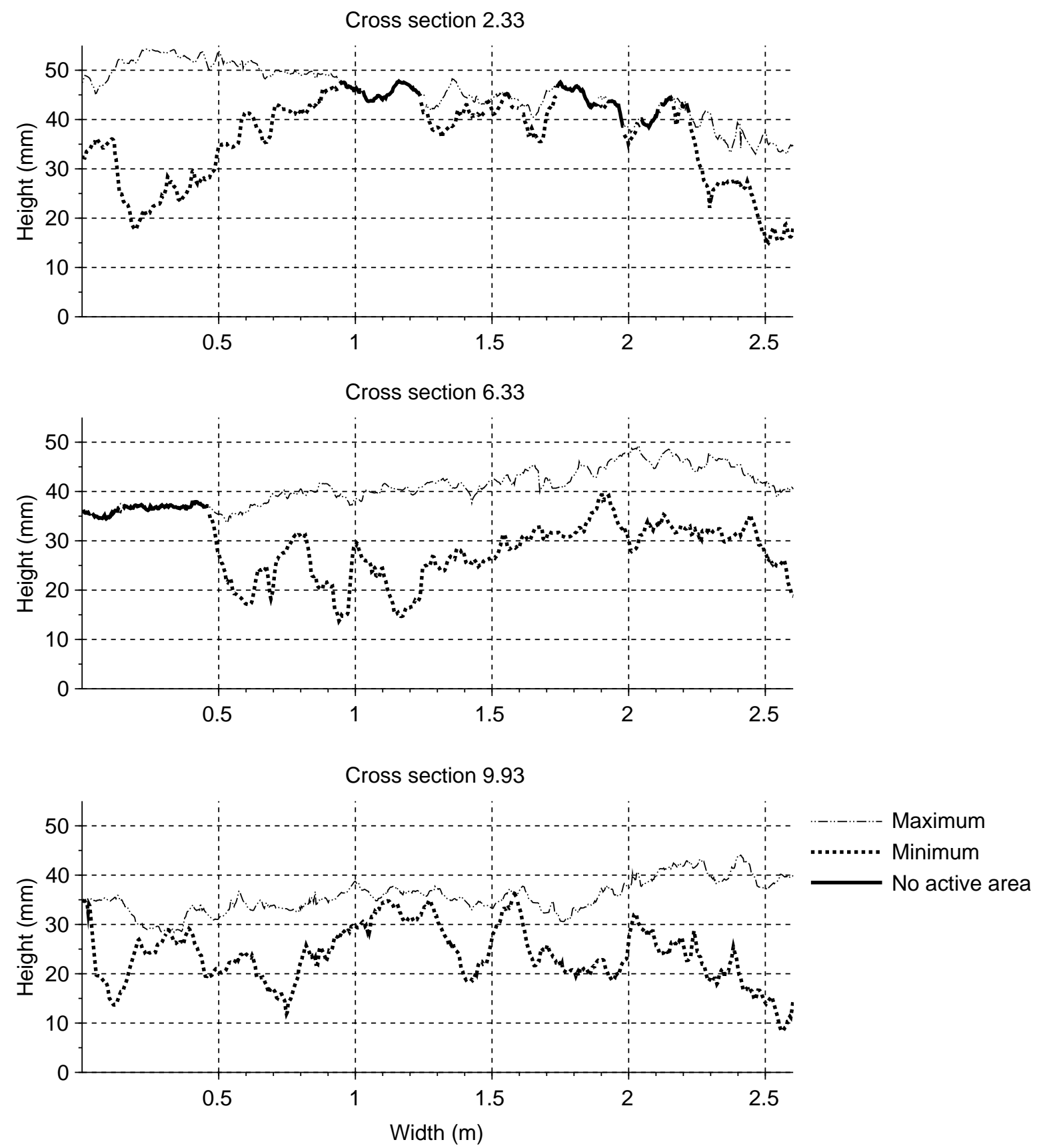

This article is protected by copyright. All rights reserved. 

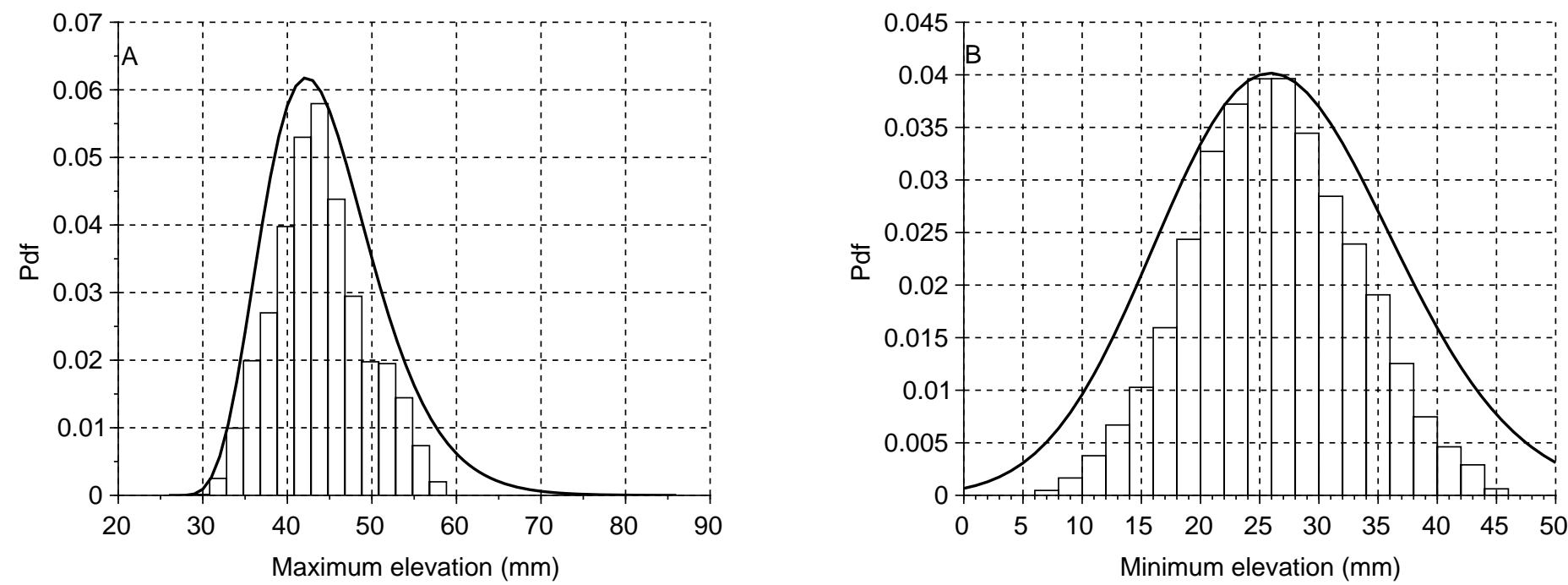

This article is protected by copyright. All rights reserved. 

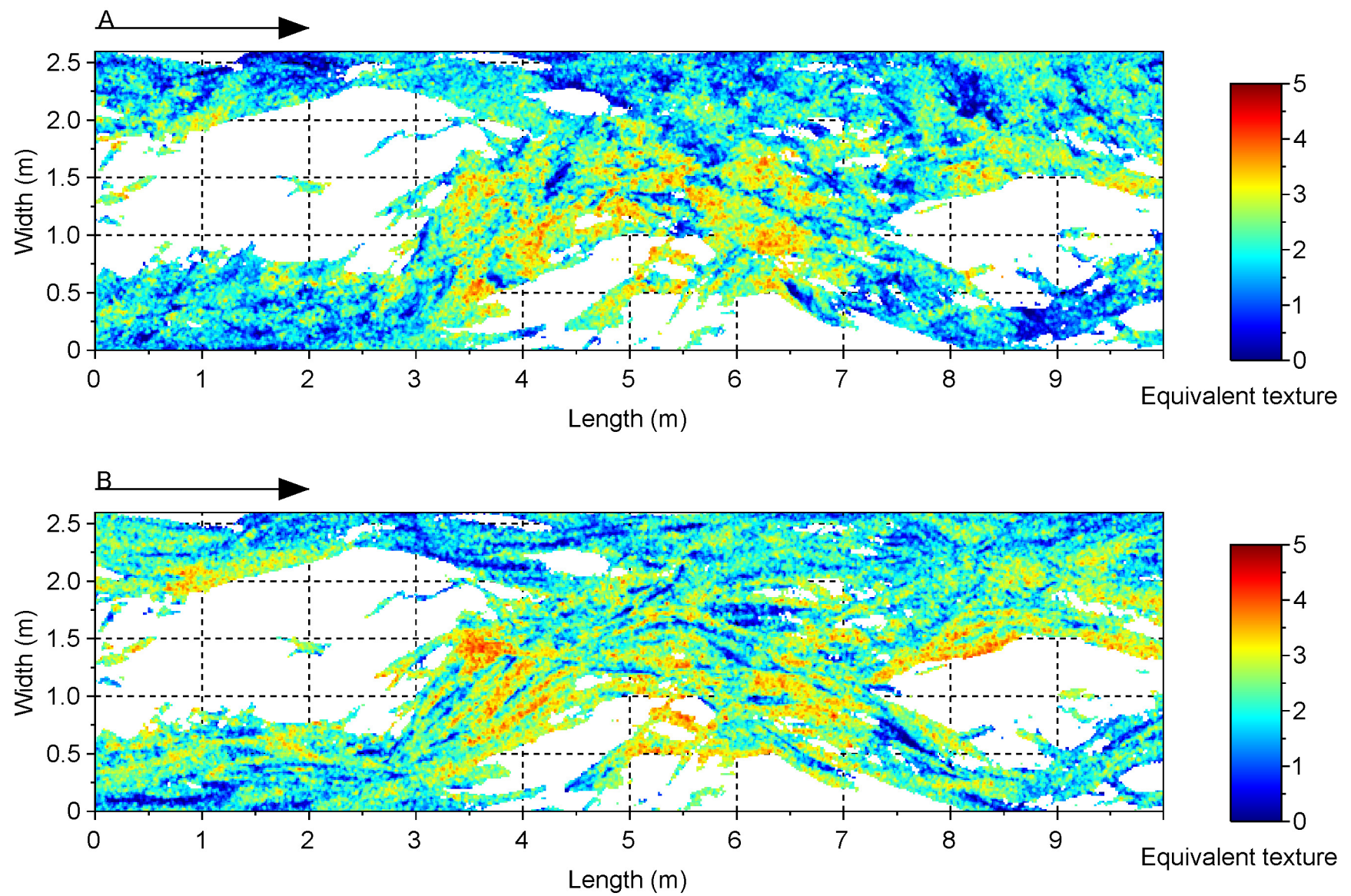

This article is protected by copyright. All rights reserved. 

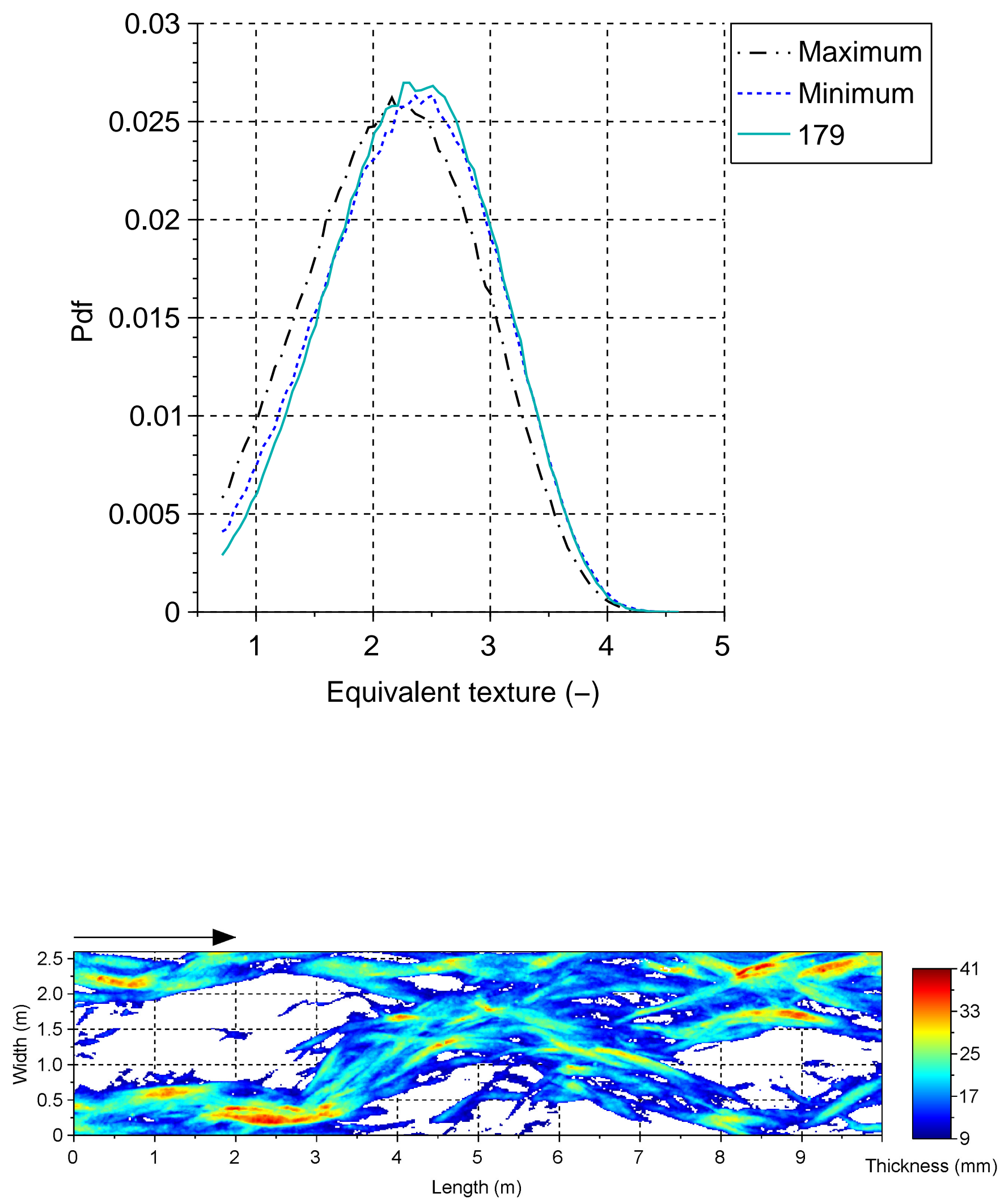

This article is protected by copyright. All rights reserved. 


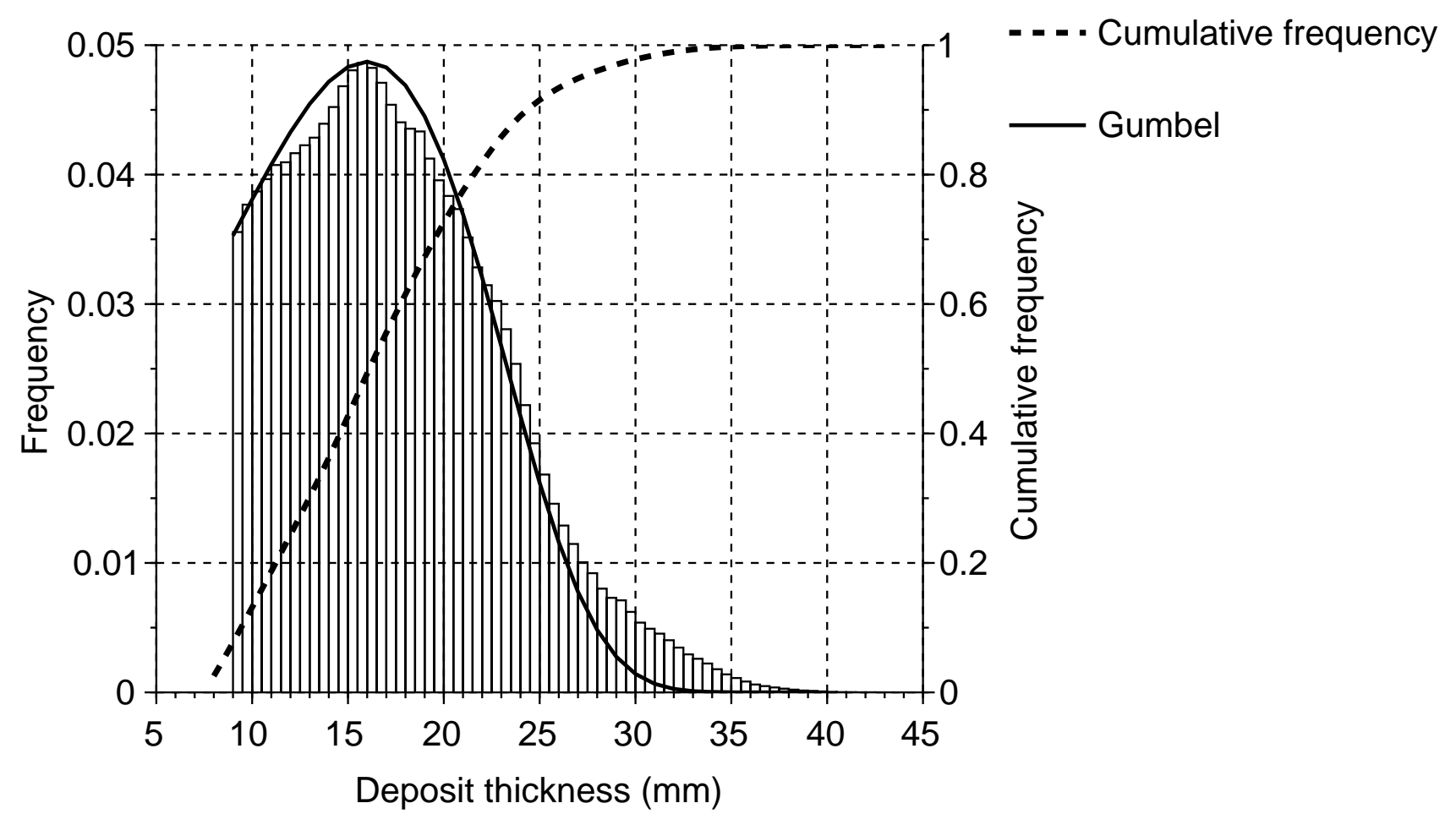

This article is protected by copyright. All rights reserved. 

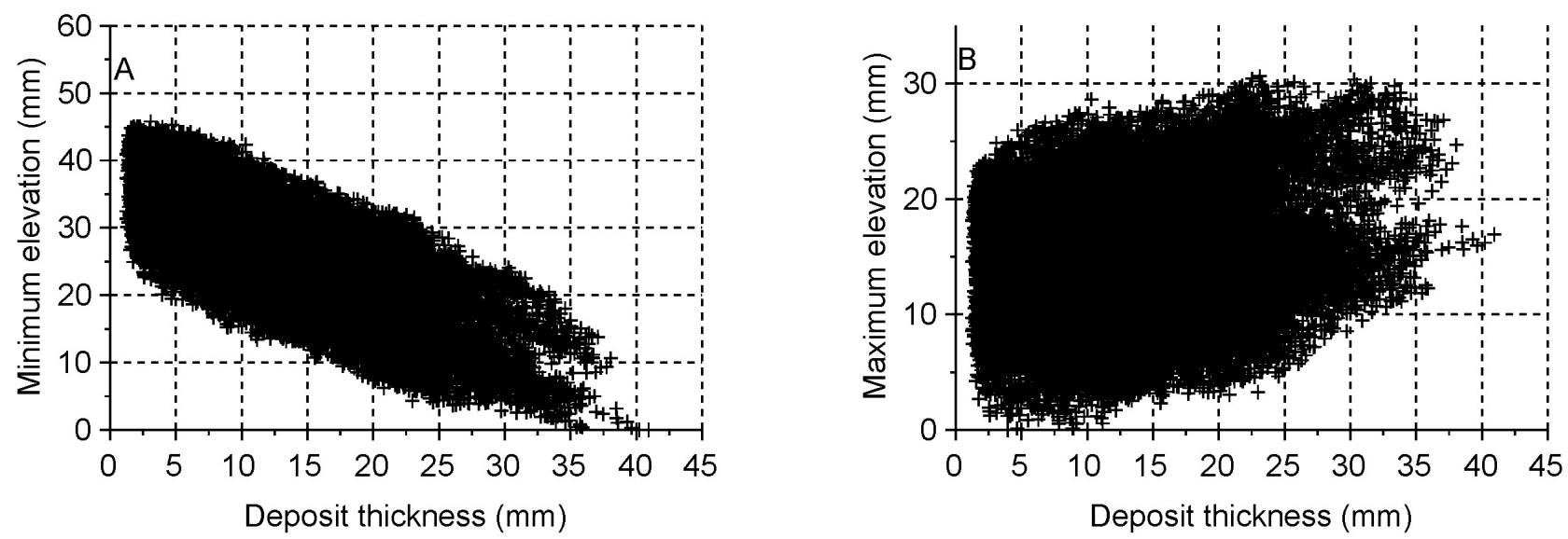

This article is protected by copyright. All rights reserved. 

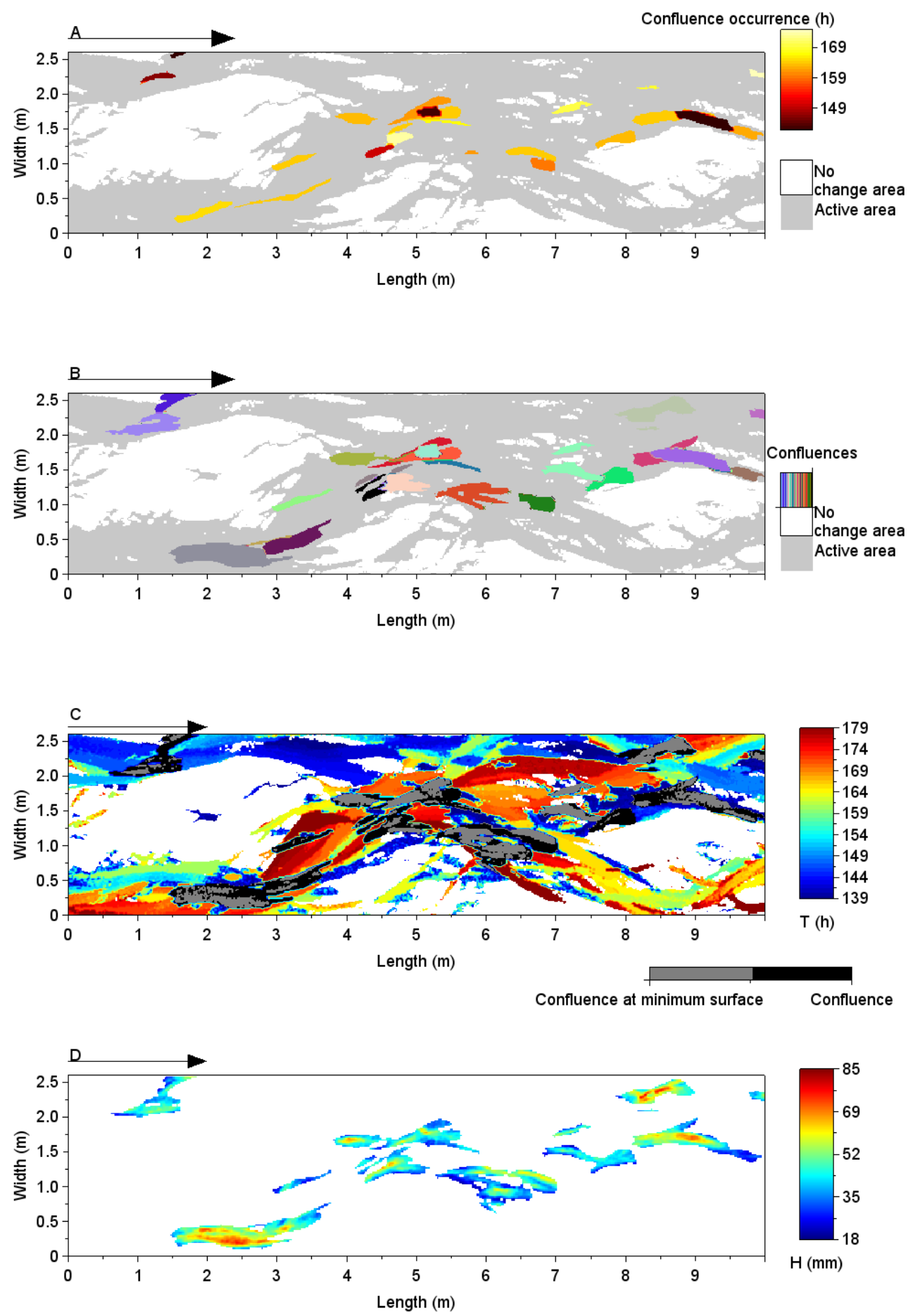

This article is protected by copyright. All rights reserved. 


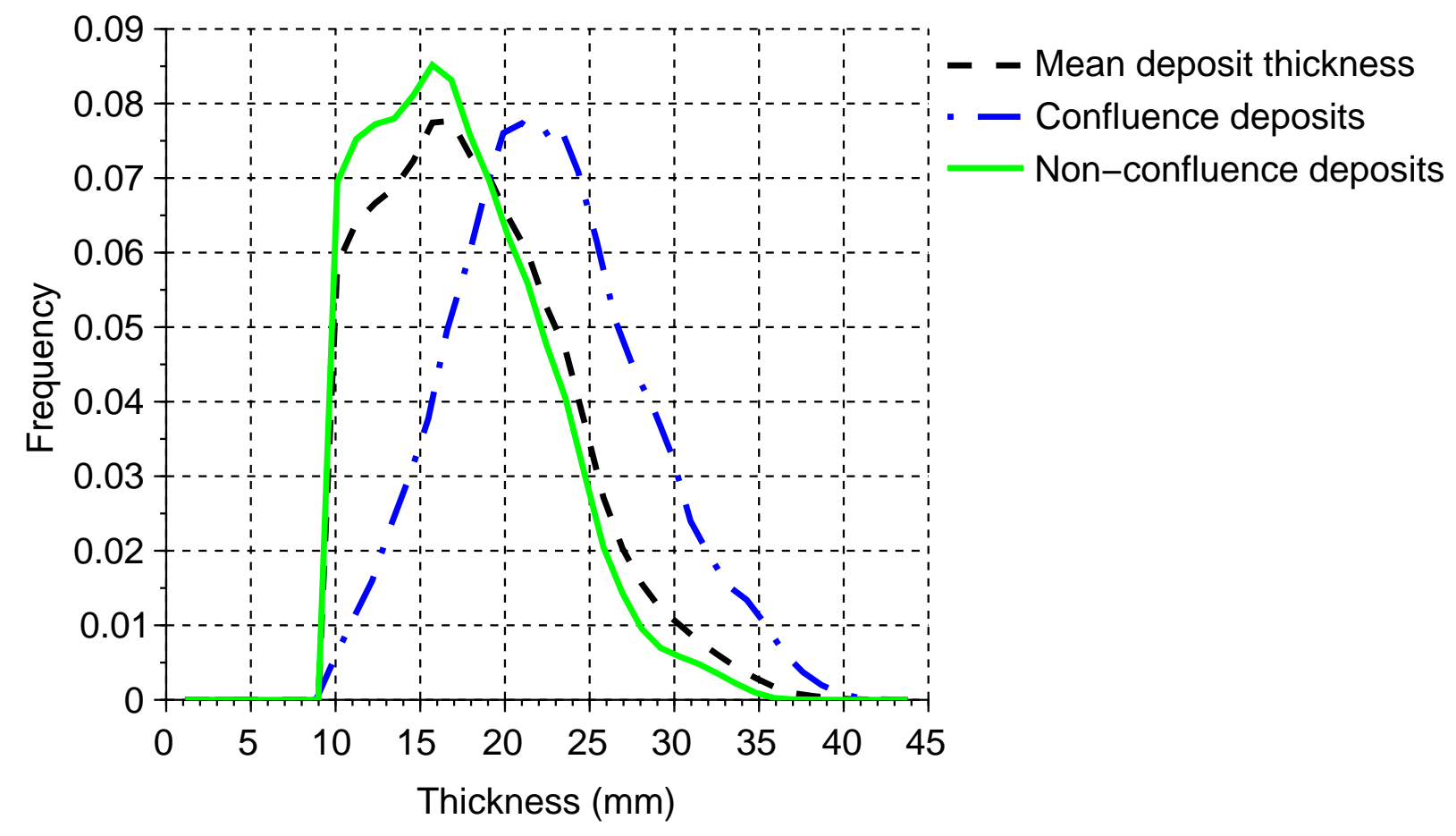

This article is protected by copyright. All rights reserved. 